Prace Komisji Geografii Komunikacji PTG Prace Komisji Geografii Komunikacji PTG
Transport Geography Papers of Polish Geographical Society

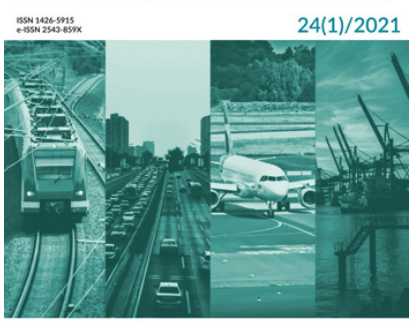

Transport Geography Papers of Polish Geographical Society

2021, 24(1), 7-30

DOI 10.4467/2543859XPKG.21.001.14944
Received: 14.05 .2021

Received in revised form: 18.06.2021

Accepted: 18.06 .2021

Published: 30.06 .2021

\title{
APPLICATION OF INTELLIGENT TRANSPORTATION SYSTEMS IN ANALYSES OF HUMAN SPATIAL MOBILITY IN CITIES
}

\section{Zastosowanie inteligentnych systemów transportowych w analizach mobilności przestrzennej ludzi w miastach}

\section{Marta Borowska-Stefańska (1), Michał Kowalski (2), Paulina Kurzyk (3), Miroslava Mikušová (4), Szymon Wiśniewski (5)}

(1) University of Lodz, Institute of the Built Environment and Spatial Policy, Lodz, Poland Kopcińskiego St. 31, 90-142 Łódź, Poland marta.borowska@geo.uni.lodz.pl; corresponding author

iD https://orcid.org/0000-0003-2448-4778

(2) University of Lodz, Institute of the Built Environment and Spatial Policy, Lodz, Poland Kopcińskiego St. 31, 90-142 Łódź, Poland michal.kowalski@geo.uni.lodz.pl

D https://orcid.org/0000-0001-7082-5161

(3) University of Lodz, Institute of the Built Environment and Spatial Policy, Lodz, Poland Kopcińskiego St. 31, 90-142 Łódź, Poland paulina.kurzyk@geo.uni.lodz.pl

(iD) https://orcid.org/0000-0003-2366-024X

(4) Department of Road and Urban Transport, University of Zilina, Univerzitná 8215/1, 01026 Zilina, Slovakia,

miroslava.mikusova@fpedas.uniza.sk

(iD) https://orcid.org/0000-0002-4669-3784

(5) Institute of the Built Environment and Spatial Policy, University of Lodz, Lodz, Poland Kopcińskiego St. 31, 90-142 Łódź, Poland szymon.wisniewski@geo.uni.lodz.pl

iD https://orcid.org/0000-0001-5488-5949

\section{Citation:}

Borowska-Stefańska M., Kowalski M., Kurzyk P., Mikušová M., Wiśniewski S., 2021, Application of Intelligent Transportation Systems in Analyses of Human Spatial Mobility in Cities, Prace Komisji Geografii Komunikacji PTG, 24(1), 7-30.

\begin{abstract}
This article contains results of studies on the applicability of data from Intelligent Transportation Systems (ITS) for the purposes of geographical studies regarding the spatial mobility of inhabitants within a big city. The article focuses on the option of applying two types of sub-systems - induction loops and automatic number-plate recognition (ANPR) - and includes examples of analyses based on the resulting data, which can serve as a basis for mobility studies. The area on the example of which the capabilities of application of ITS data have been presented is Lodz - a large city in central Poland. The conducted research shows that ITS systems offer an enormous potential in providing data for spatial mobility studies. In order to fully exploit its worth, however, it is imperative to expand the research procedure by including, for instance, the results of qualitative research. Also, the interpretation of results obtained on the basis of ITS data ought to be performed with an awareness of numerous significant preliminary and simplifying assumptions.
\end{abstract}

Key words: ITS; spatial mobility, transport geography, induction loops, ANPR 


\section{Introduction}

Travelling is a significant part of our life. Every day we move from one location to another in order to complete our goals and perform our duties related to work, education, and social and cultural matters, and by doing so, we generate traffic. 'Mobility is defined as a set of activities related to the movement of people and all other actions necessary to make this movement possible' (Nosal, Starowicz, 2010, p. 26). Mobility happens to be the subject of research within numerous branches of science. In geography, i.e. a science that is thoroughly spatial, research on mobility is, for the most part, aimed at analysing processes of territorial mobility in specific geographical conditions (Nutley, Thomas, 1995; Kraft, 2014). Kaufmann (Kaufmann et al., 2004, p. 746) notices that 'spatial mobility traditionally refers to geographic displacement, i.e. the movement of entities from an origin to a destination along a specific trajectory that can be described in terms of space and time. Entities can be concrete (e.g. consumables, machinery or people) or abstract (e.g. information, ideas or norms). During this journey, entities may not only experience a change in status (e.g. value or importance), but the spatial mobility of entities may also influence the points of departure, traversal or destination'. Analyses regarding mobility involve studies on migration, tourism, and residential and daily mobility within cities (Jirón, 2009).

As Zmuda-Trzebiatowski (2016) points out, in the assessment of transport systems, the following five components should be taken into account: transport, space, time, user and the ability of people to interact with the transport system. These components should be interconnected so that the system functions as optimally as possible. Therefore, without identifying and taking into account the transport behavior of people during the study, mobility will constitute a research gap. The study of human transport behavior is a complex and difficult issue, which, as Sołtyszek (2011) emphasizes, human behavior is a coordinated action in relation to a given environment, which is to lead to the achievement of the chosen goal. Moreover, this behavior is the result of the influence of external stimuli to which each person will react differently.

Nowadays, a large number of modern metropolises face challenges related to the reduction of the negative effects of human activity, including the consequences directly connected with mobility, which is mainly conducted by means of private car transport. Not only do modes of road transport generate noise and pollute the air, but also their movement results in congestion, parking difficulties, as well as collisions and accidents (Pucher et al., 2005; Hagman, 2006;
Shawe-Taylor et al., 2006; Costabile, Allegrini, 2008; Nosal, Starowicz, 2010; Dąbrowska-Loranc, LeśniowskaMatusiak, 2011; Kochanowska, 2011; Nosal, 2011; Rastogi, 2011; Sierpiński, 2012; Ciastoń-Ciulkin, 2014; Garcia et al., 2016). In order to alleviate such mobility-related consequences and to introduce systems of sustainable transportation, a number of miscellaneous instruments, tools, methods and strategies are applied in what is known as mobility management. This encompasses all the measures regarding the planning, organisation, co-ordination and control of the movement of people and cargos. One such measure is Intelligent Transportation Systems (ITS) (Bazzan, Klügl, 2014; Nosal, Starowicz, 2010).

Intelligent Transportation Systems are often discussed in the context of the function and influence of transport (Ambak et al., 2009; Marczak, Kozłowski, 2014). Intelligent Transportation Systems offer an extremely wide scope of miscellaneous tools based on IT, wireless communications, and automotive electronics. They allow for effective and efficient management of transport infrastructure and public transport provision. Within such systems, the functioning of transport is, to a great extent, supported by integrated measuring (sensors, detectors), telecommunication, IT, and informative and automated solutions (Anagnostopoulos et al., 2006; Koźlak, 2008; Filjar et al., 2009). The main purpose of such systems is to manage vehicles, cargos and routes, which results in increased road safety, reduced congestion and travel times, and improved fuel efficiency (Proper, 2001; Litwin, 2003; Costabile, Allegrini, 2008; Koźlak, 2008; Ambak et al., 2009; Toral et al., 2010; Pauer, 2017). 'Intelligent technologies and services are considered to have great potential, but on the other hand, e.g. due to reasons of privacy, security or public-private role divisions, they also pose great challenges to the transport system' (Tuominen, Ahlqvist, 2010, p.121). Intelligent Transportation Systems are also one of the key constituents of urban development based on the concept of the Smart City (Xiong et al., 2012; Sikora-Fernandez, 2013; Stawasz, Sikora-Fernandez, 2015).

The functioning of Intelligent Transportation Systems is also crucial in the context of implementing systems of autonomous vehicles (Campbell et al., 2010), which one day may themselves be capable of detecting ITS systems (Gerla et al., 2014), since these systems can serve as a platform for such communication models as vehicle-to-infrastructure (V2I) (Milanes et al., 2012), vehicle-to-vehicle (V2V) (Biswas et al., 2006), and inter-vehicles-to-infrastructure (V2V2I) (Miller, 2008). An efficient ITS system within the urban area undoubtedly gives a city a competitive advantage in implementing systems of autonomous vehicles, e.g. with regard to servicing public transport. 
Numerous publications have been devoted to the debate about the technological value of Intelligent Transportation Systems and their role in creating urban mobility, including articles on IT (Santa et al., 2008; Xiong et al., 2012), transport engineering (Slinn et al., 2006), and transport telematics (Barceló et al., 1999; Wang, 2005; Mikulski, 2010; Buch et al., 2011).

Bearing in mind the aforementioned properties of Intelligent Transportation Systems, one must also emphasise their considerable role as a source of geographical data. At each stage of its operation, such a system is concurrently a provider and a user of vast resources of data. When a system is being built, or more precisely when its variant adjusted to any given transport system is being developed (individual manufacturers have a basic version which they only adjust to the needs of the city where it will operate), the ITS remains operational and relies on diagnostic data. Once the system has been implemented - both the software and the hardware (devices in the command centre and within the transport network of the city, e.g. induction loops, and ANPR and CCTV cameras) - it requires calibration, the purpose of which is, first of all, to prepare the system for the specific working conditions of any given city, and secondly, to make it meet the requirements of the applied transportation policy (e.g. in the form of priorities for individual means of transport). During this phase, the system 'learns' the transportation behaviours of local residents, which requires the widest available data resources. Having been utilised by the system, the data is stored on the servers of the system provider or the client (e.g. city hall authorities), depending on the conditions stipulated by the parties in the agreement. The calibration phase is followed by a period of regular system operation, involving a continuous collection of data on vehicle flows within the monitored area, which enables an evaluation of the efficiency of the implemented solutions within the applied transport policy, recognition of emergency situations (e.g. transport behaviour following a collision or a road accident, closures of network segments due to maintenance works or mass public events), and the assessment of how effectively the employees of the command centre make interventions within the system.

From the research perspective of transport geography, the aforementioned data resources constitute an invaluable base of information on the functioning of transport in any given area. Its value stems, in the first place, from the spatial range of the research and the sheer number of measuring points, which would otherwise be unattainable in purely scientific or academic studies. Secondly, an ITS system provides precise data which is exceptionally accurate in terms of timing and frequency of measurement (continuous measuring, aggregation of data from inductive loops every 15 minutes).

The purpose of this article is to present how the data obtained from an Intelligent Transportation System might be applied in analyses of human spatial mobility. The data for the study was derived from a Regional Traffic Control System (RTCS) which was implemented in 2015 in Lodz, one of Poland's largest cities. Examples of the application of ITS data refer, in particular, to the subsystem related to induction loops and automatic number-plate recognition (ANPR) cameras.

\section{Properties of the system}

The data presented in this article comes from the Regional Traffic Control System operating in the city of Lodz, which is a large urban agglomeration with a total area of 293 square kilometres and a population of nearly 700,000 located in central Poland, at the intersection of the main north-south and east-west transport routes. In the last few years, the city - just like the rest of the country - has undergone a number of significant transformations both in transport infrastructure (Nowak, Sikora, 2005; Dudek, Ochelska-Mierzejewska, 2016) and the operation of the entire transportation system (Barwiński, Kotas, 2015a; 2015b). One of the key investments in the area was the implementation of an ITS system intended to solve the transport issues the city faced (e.g. congestion, unreliability of public transport), and to implement solutions concordant with sustainable transport, and - more generally speaking - with sustainable mobility. The system was implemented on December 1, 2015 (it was operational, though a large number of intersections were still not connected to the system) (Barwiński, Kotas, 2015a, Wiśniewski, 2016). The implemented software of choice was the Sydney Coordinated Adaptive Traffic System (SCATS), which is a system managing the timing of signal phases at traffic lights. SCATS was developed in the 1970s as a tool used by Sydney traffic engineers. 'The SCATS system monitors the traffic in a network and controls the signals - based on volumes and occupancy - and imposes coordination control strategy between neighbouring intersections based on certain criteria. Traffic volumes and occupancies, essential inputs to the SCATS system, are measured by loop detectors located on a short distance before the stop lines' (Li et al., 2014). In order to implement the system, old traffic signals were modernised, and new traffic lights were installed at 234 intersections, and connected to the Lodz Regional Tram system (a rapid tramway connection between Lodz and its satellite towns). During this stage, a network of induction loops was also installed. 
What is more, the system was expanded with a GIS application (geographic information system), which allows basic spatial operations on transportation system data (e.g. visualisation on background maps). Crucial to the effective operation of the ITS system is a connectivity subsystem, which is responsible for the information flow between individual participants in the process of transport management within the city (e.g. driver notification systems such as variablemessage signs). Another significant element of the system is the use of ANPR cameras for intelligent number plate recognition. In Lodz, there are currently 125 such cameras installed at 23 intersections. Drivers are also informed about the current capacity of the city's road network by variable-message signs, deployed at critical locations within the network, i.e. spots where extra-urban traffic joins the intra-urban system, and displaying current travel times between specified locations. An important constituent of the Lodz transportation system is the road stretching across the city centre from east to west, which - in its central section - passes through the tunnel serviced by the Supervisory control and data acquisition (SCADA) system. Naturally, this ITS system also incorporates the city's public transport. In that matter, one of the implemented solutions is the Dynamic At-Stop RealTime Information Display System managed by the Public Transportation Management System. What is more, a properly equipped Traffic Control Centre was also opened in the city. Additionally, the ITS system is supported by a CCTV network of 88 cameras mounted at 82 intersections, but the recorded footage does not constitute a potential source of data for the analysis of vehicle flows. The quality of the picture may be high, but any further processing is ruled out due to such properties as the different distances from recorded vehicles, the various filming angles, and the lack of a lighting system which could be activated for recording at night. While searching for possibly the broadest application of the ITS-derived data for geographical analyses, it was initially assumed that the CCTV footage would be re-analysed by the ANPR software, and thus it would supplement the material obtained from ANPR cameras. Unfortunately, due to the aforementioned reasons, this was impossible with the software and devices currently available on the market.

The whole system is complemented by a website for travellers and public transport drivers, created in order to visualise the public transport and road traffic situation within the ITS system (Barwiński, Kotas, 2015a).

Therefore, it must be emphasised that only the data from induction loops and ANPR cameras was of value for the research of human spatial mobility. Though it could be assumed that special attention ought to be paid to the public transportation subsystem, it does not register passenger flow, concentrating exclusively on the movement of vehicles, and thus duplicates, to a great extent, the information listed in timetables (only adding data on possible discrepancies in the network of connections). Furthermore, it is also included by induction loops and ANPR cameras (naturally, within the area of the city covered). Therefore, this data source has not been included in the considerations elaborated on in this article.

As far as the general deployment of the system measuring devices (induction loops and ANPR cameras) is concerned, it must be indicated that they are mostly concentrated in the city centre, and if they are found outside its perimeter, they tend to be along key arterial thoroughfares running along the north-south and east-west axes (Fig. 1). Such deployment has a great impact on subsequent conclusions, drawn on the basis of the results returned in the course of the research performed on the indicated data. Obviously, the denser the measuring network in any given area is, the more accurate and true-to-life the conclusions will be. There are also numerous problematic issues the solution of which cannot be based on sui generis interpolations and extrapolations of the data obtained from the ITS measuring devices. Such limitations are discussed later in this article.

When analysing ITS-derived data, one must also be aware that the spatial mobility 'recorded within it' - i.e. people's communication behaviours - is not entirely 'natural', since the ITS system itself influences flows by privileging trams and the duration of traffic signal phases, for example. What is more, some temporary interventions, taken at the level of the Traffic Control Centre, do happen within the system. Obviously, although this is a natural part of an urban transportation system, one must be aware that the picture emerging from the analysis of the ITS-derived data does not stem exclusively from the decisions taken by road users. Thus, it would be extremely valuable to juxtapose the results of analyses based on the data derived from ITS measuring devices prior to the activation of the system with the data following the implementation of the target solutions. Then it would be possible to draw conclusions on the influence that the manner in which the ITS system operates has upon the shaping of communication behaviours (on the assumption that other factors are invariable).

\section{Induction loops}

An inductive loop sensor, commonly known as an induction loop, is one of the most popular detectors applied in the measurement of road traffic parameters. The device owes its popularity to its adequate performance and metrological characteristics (Gajda et al., 


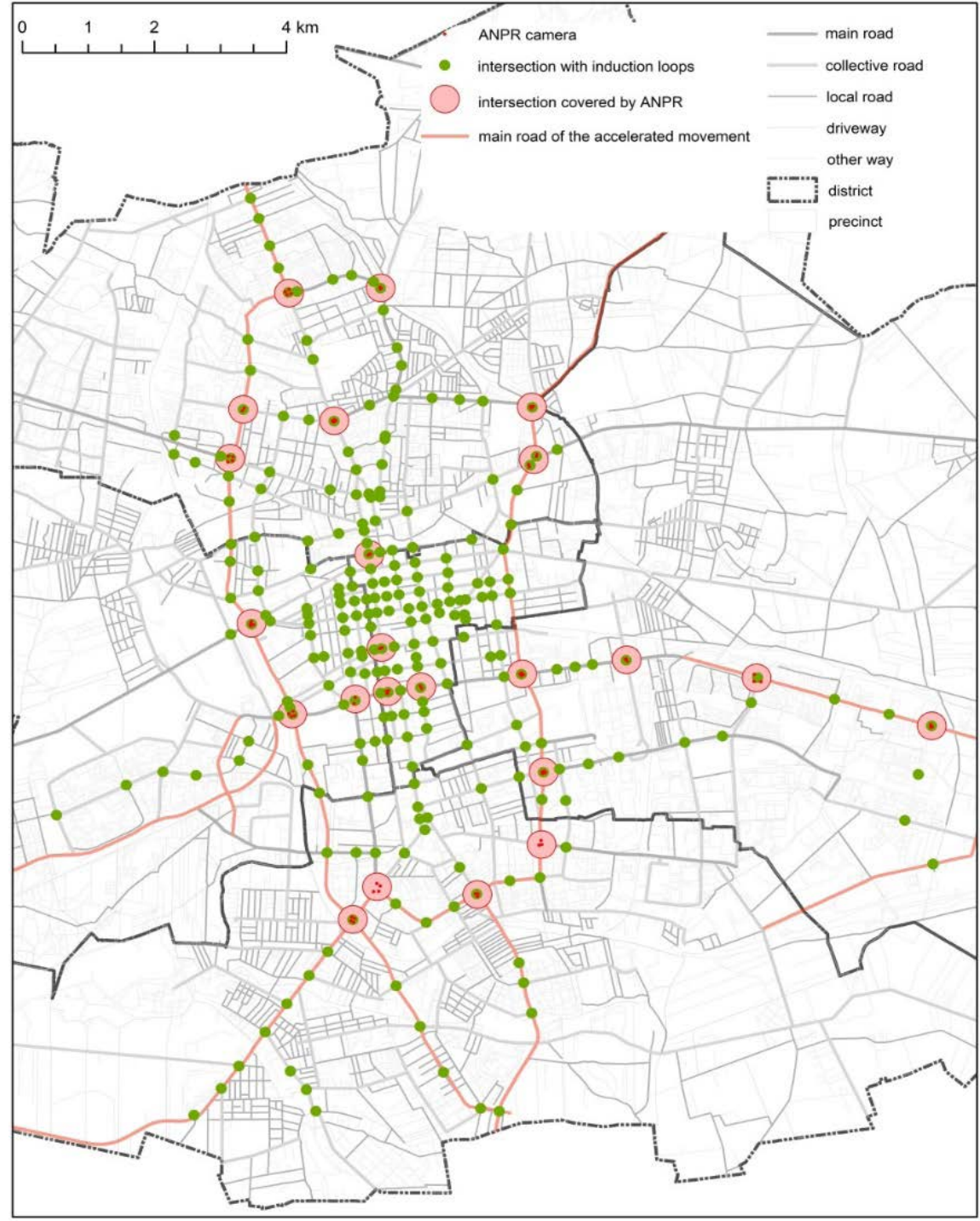

Fig. 1. The deployment of RTCS inductive loops and ANPR cameras in Lodz.

Source: authors' own elaboration.

2001). Inductive loop sensors used for the measurement of road traffic parameters usually take the form of rectangular loops, ranging from $1 \mathrm{~m} \times 1 \mathrm{~m}$ to $3 \mathrm{mx}$ $3 \mathrm{~m}$. Sizes of any given sensors are determined by their projected duties (measuring various parameters of the travelling vehicle, managing traffic lights, activating other systems, e.g. cameras) and the expertise of the system designers (Burnos et al., 2007). The operation of an inductive loop is based on the phenomenon of eddy currents, which occurs whenever a metal object can be found within the area influenced by a changing magnetic field. The magnetic field penetrates the encountered metal object, inducing a flow of electric current (Burnos et al., 2011).

The functioning of induction loops can be impeded by various types of errors and failures, resulting for example in faulty vehicle count results (Li et al., 2014). Such errors may concern the loop itself as well as other devices by means of which the data recorded by the loop is sent to the Traffic Control Centre. What obstructs the optimum operation of the ITS system in respect of managing and servicing induction loops is a situation when one of the installed loops is not connected to the global system. An example of an error which can be very damaging to the analysis of the data from induction loops with regard to spatial mobility is 'freezing' or the wrong calibration of the device, which - systematically and at a set time interval - displays the same and often inflated result, or - in more favourable circumstances - returns warnings about a measurement error (depending on the type of error, a BAD or DA message is displayed within the SCATS system). This may lead to an upward or downward bias regarding the load of any given spot within the road network, and dramatically impact the research results. Therefore, it is imperative to verify data upon its retrieval from the ITS system, since the system itself does not detect such errors. While in the 
case of microscale studies this issue can be solved through meticulous verification of the network load in a specified period of time and within a limited area, e.g. by comparing measurement results from neighbouring sets of independent detectors (Kowalski, Wiśniewski, 2017b), on a district, whole city or even agglomeration scale, it is necessary to conduct statistical analyses which, in the initial phase, allow the deletion of extreme measurement values (including faulty and extremely high results), and then, depending on the needs, the process of their averaging, etc.

A crucial stage of working on data from the ITS system is the very instant when it is collected from the source base and then prepared for an analysis in the environment of Geographical Information Systems and spreadsheet programs. This is the phase which, first of all, will determine the size of the error that the whole research will be skewed by, and also the level of difficulty of any further work on the data. Naturally, it is possible to acquire a complete database for any given time interval, but it will be next to useless for the purposes of spatial analysis. In order to fully exploit the potential of this research material, it is necessary to derive the data and simultaneously view the construction of any given intersection that is equipped with specific induction loops. This allows the researcher to describe each of them with an attribute of a specific lane and direction of traffic flow. In further analysis, this information is crucial in evaluating the number of vehicles for individual sections of the road network. The source data takes the form of a text file and is aggregated for individual loops at every single intersection. Therefore, in order to perform holistic research, the data must be converted into a numeric format (e.g. CSV files) and then merged into a single database (Fig. 2).

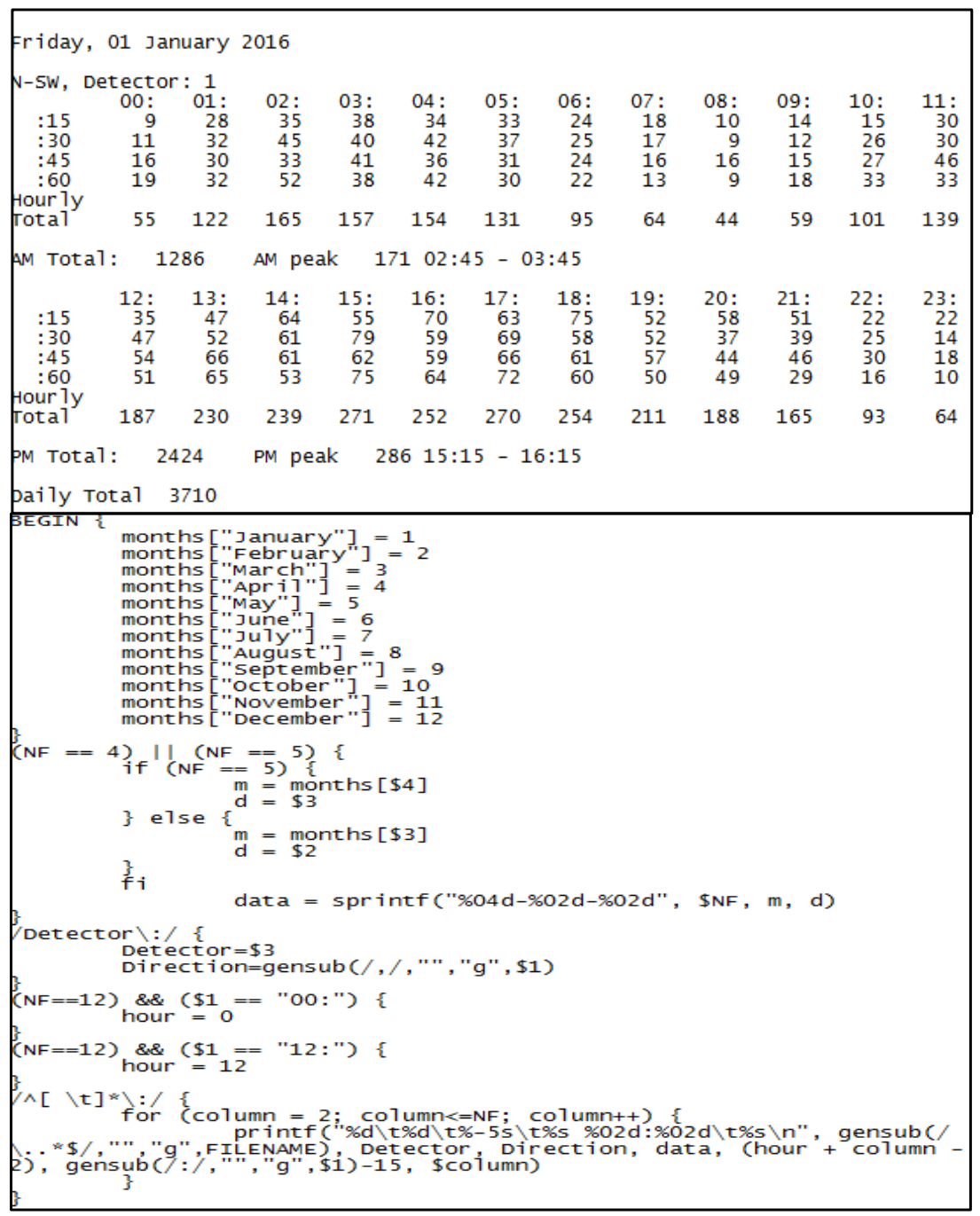

Fig. 2. An illustrative base of data derived from the SCATS system containing the distribution of the numbers of vehicles for individual time intervals on a single day at one of the detectors (top), and an example of the .awk script processing it into a database which can be interpreted by statistical software and GIS (bottom). 
The row in the resultant database corresponds with the instant (date and hour) at which the system obtained information about a cumulated number of vehicles for the latest measurement period (which, in the case of the analysed ITS system, equals 15 minutes). Thus, each row contains information on the number of vehicles, the ID number of the induction loops, the ID of the intersection within which the loop is installed, the direction of traffic flow for the lane, and the direction of traffic flow available upon exiting the intersection. The aforementioned conversion is based on a relatively simple script, written in an interpreted programming language, for example. After identifying the right pattern in the initial tables, one must use it to process these tables into the targeted database format (Fig. 2). A correctly prepared database (Tab. 1) makes it possible, through such simple features as sorting, filtering and aggregation, to generate the desired reports or tables, which are compatible with GIS.

Regardless of the fact that the presented data contains information which is rather simple to interpret, its completeness as well as its time and spatial range allow us to perform numerous analyses and draw conclusions in the course of completing various cognitive goals. Basic analyses based on the data from induction loops may regard time and spatial differences in vehicle traffic load (Fig. 3) for individual lanes or intersections (upon aggregation by an intersection ID number).

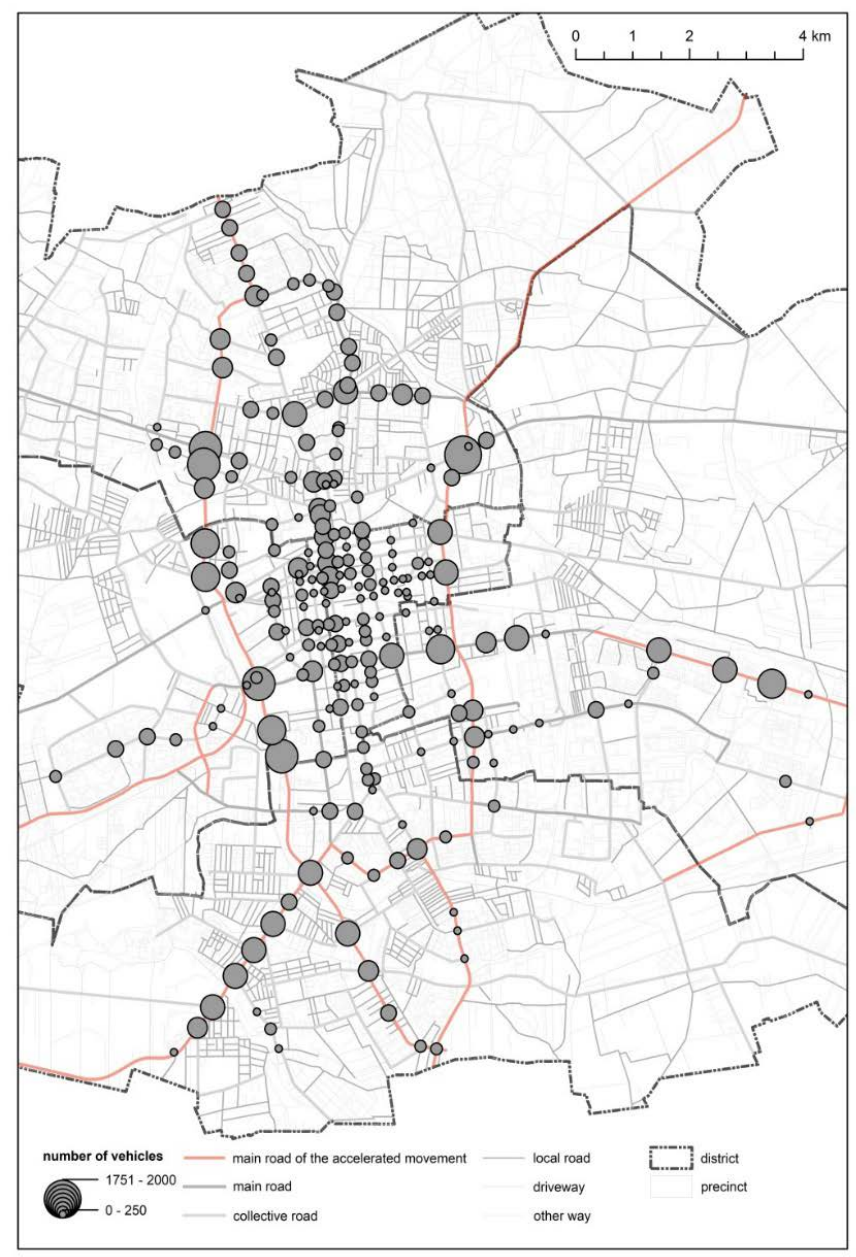

Fig. 3. Number of vehicles during a morning rush hour in Lodz. Source: authors' own elaboration, based on Kowalski, Wiśniewski, 2017a.

Tab. 1. An extract (several selected rows) of the base of data from the SCATS system upon its processing for the purposes of GIS.

\begin{tabular}{|c|c|c|c|c|c|}
\hline Crossroads_id & Detector_ID & Direction_from_to & Day_date & Time & Number_of_cars \\
\hline 8244 & 3 & S-N & $01-01$ & $16: 45$ & 40 \\
\hline 8244 & 4 & S-N & $01-01$ & $16: 45$ & 21 \\
\hline 8244 & 5 & S-NE & $01-01$ & $16: 45$ & 21 \\
\hline 8244 & 6 & N-NE & $01-01$ & $16: 45$ & 3 \\
\hline 8244 & 7 & N-S & $01-01$ & $16: 45$ & 13 \\
\hline 8244 & 8 & N-S & $01-01$ & $16: 45$ & $16: 45$ \\
\hline 8244 & 9 & N-W & $01-01$ & $16: 45$ & 2 \\
\hline 8244 & 10 & N-W & $01-01$ & $16: 45$ & 1 \\
\hline 8244 & 12 & W-N & $01-01$ & $16: 45$ & 1 \\
\hline 8244 & 13 & W-N & $01-01$ & $16: 45$ & 0 \\
\hline 8244 & 14 & W-NE & $01-01$ & $16: 45$ & 0 \\
\hline 8244 & 15 & W-S & $01-01$ & 0 \\
\hline
\end{tabular}

Source: authors' own elaboration. 
Another basic analysable variable is the spatial diversity of vehicle numbers with regard to directions of traffic flow (Fig. 4).

This basic information on people's spatial mobility makes it possible to conduct numerous problemrelated analytical studies, one thematic group of which is the identification of how infrastructural investments municipal system renders it possible to determine the actual traffic generation, and also to perform studies on, for instance, the parking occupancy rate, the average daily vehicle traffic load, and directions from which vehicles arrive. This type of research also allows the traffic generated by the shopping mall in time intervals within the total traffic in any given

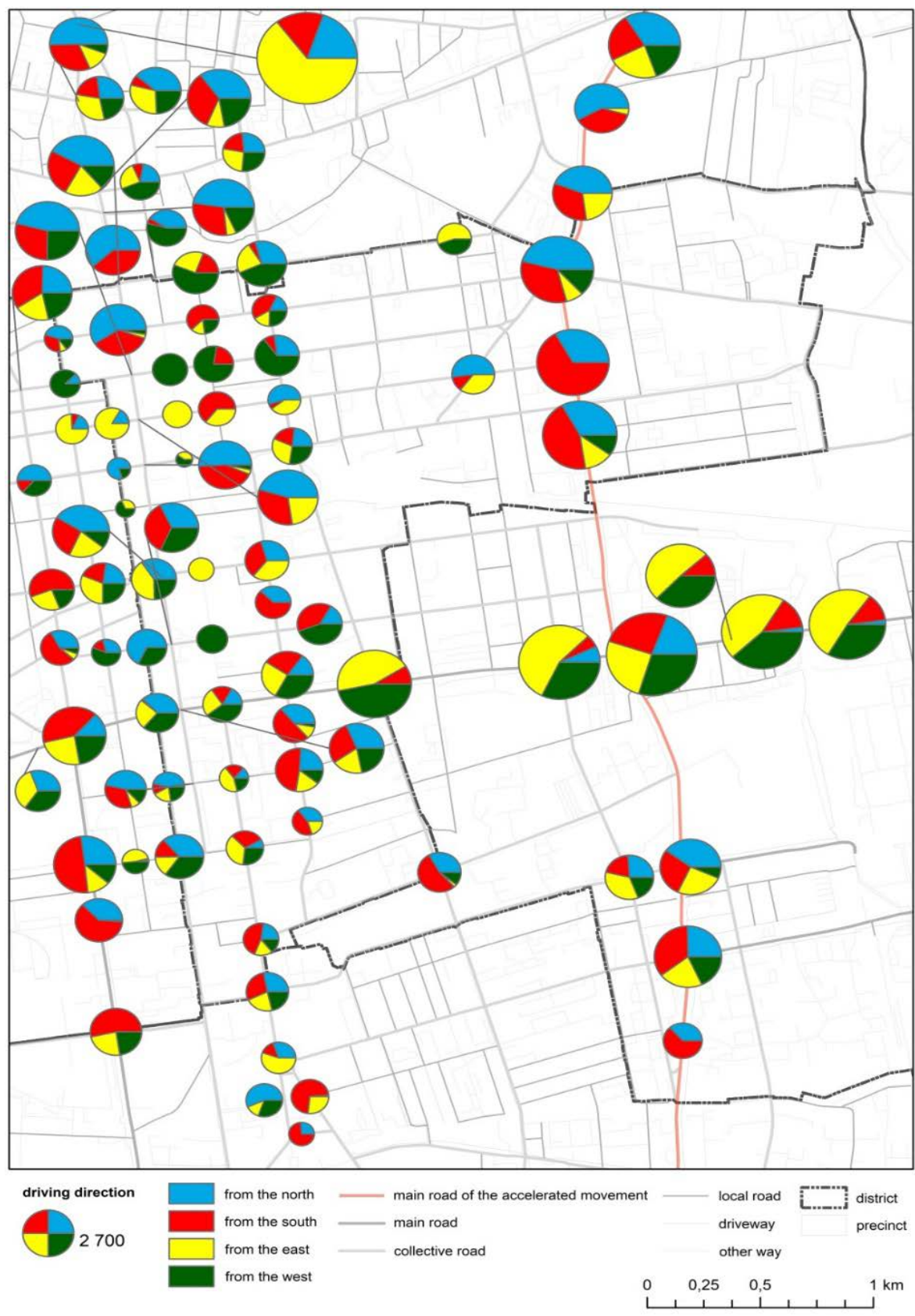

Fig. 4. Driving direction and number of vehicles in the city centre of Lodz during a morning rush hour.

Source: authors' own elaboration, based on Kowalski, Wiśniewski, 2017a.

or any other types of traffic generators (attractors) influence people's transport behaviours. An example which could be used to illustrate this is an analysis of the impact a shopping centre exerts upon the city's transportation system. The data obtained from the sector of the road network to be determined (Fig. 5) (Kowalski, Wiśniewski, 2017b).

This basic information on people's spatial mobility makes it possible to conduct numerous problemrelated analytical studies, one thematic group of which 
is the identification of how infrastructural investments or any other types of traffic generators (attractors) influence people's transport behaviours. An example which could be used to illustrate this is an analysis of the impact a shopping centre exerts upon the city's transportation system. The data obtained from the municipal system renders it possible to determine the actual traffic generation, and also to perform studies on, for instance, the parking occupancy rate, the average daily vehicle traffic load, and directions from which vehicles arrive. This type of research also allows the traffic generated by the shopping mall in time intervals within the total traffic in any given sector of the road network to be determined (Fig. 5) (Kowalski, Wiśniewski, 2017b).

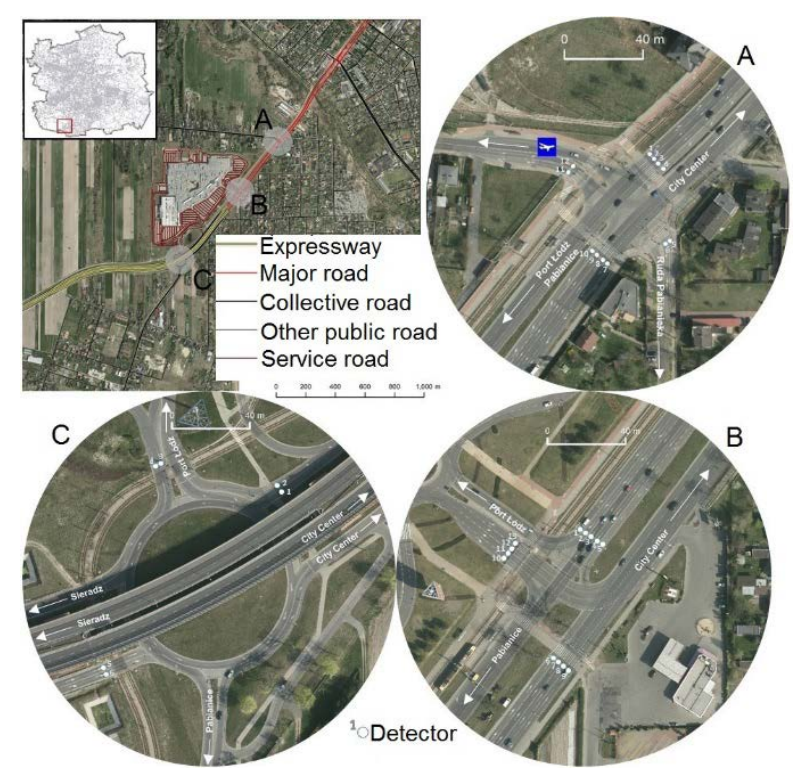

2013; Lechowski, 2016), socio-economic development (Munnell, Cook, 1990; Eisner, 1991; Singletary et al., 1995; Boarnet, 1996; Harmatuck, 1996; Lobo, Rantisi, 1999; Preston, 2001; Givoni, 2006; Li, Li, 2008; Snieska, Simkunaite, 2009; Rosik, Komornicki, 2013) and transportation behaviours (Jones et al., 1983; Kitamura et al., 1997; Kockelman, 1997; Boarnet, Sarmiento, 1998; Elhorst, Oosterhaven, 2002; Maat et al., 2005; Albert, Mahalel, 2006; Gadziński, Radzimski, 2016). The presented group of analyses fits squarely into the stream of research that combines issues related to management and transportation, and yet the perspective at which these issues are examined is quite different and closer to mobility studies (Vilhelmson, 1999; Bronk, 2009; Kraft, 2014) and research on traffic generation of
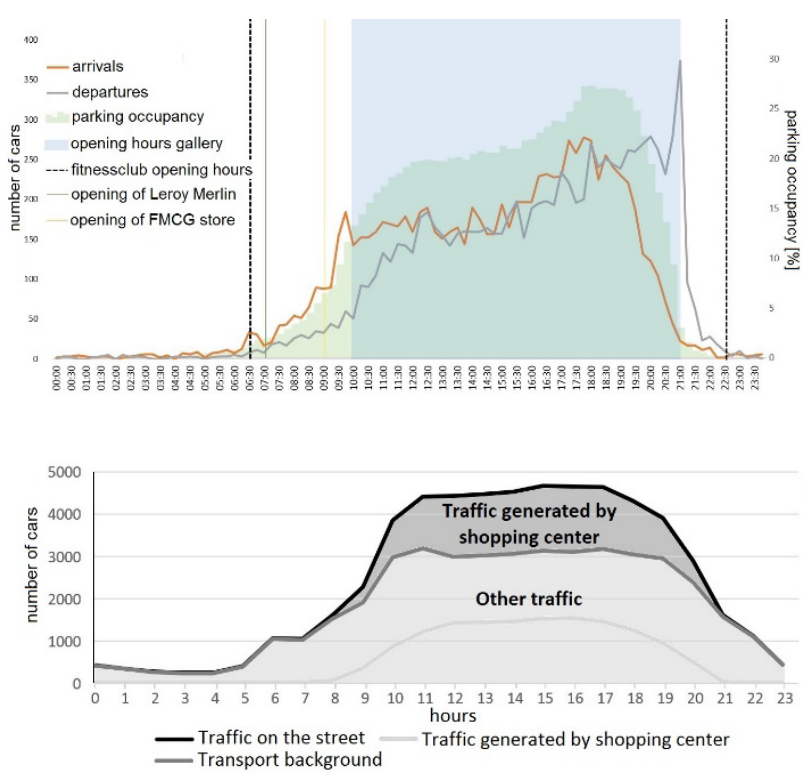

Fig. 5. The application of ITS data (induction loops) in a study on traffic generation caused by facilities and their impact on the load of the local road network. The spatial deployment of detectors (left), daily traffic load in the shopping centre and car park load (top right), and traffic load in the vicinity of the shopping centre (bottom right).

Source: Kowalski, Wiśniewski, 2017b.

Another thematic group of problem-related analyses based on the data from induction loops is combined research on traffic load and spatial management (Fig. 6). Within the science of geography, studies that combine management and components of transportation have been developed for numerous aspects such as research on accessibility (Halden, 2002; Geurs, Van Wee, 2004; Bertolini et al., 2005; Du, Mulley, 2006; Heath et al., 2006; Yigitcanlar et al., 2007; Majewski, Beim, 2008; Radzimski, 2009; Gadziński, 2010; Wiśniewski, 2016), and the influence of transport infrastructure on spatial management (Newman, Kenworthy, 1996; Wegener, Fürst, 1999; Badoe, Miller, 2000; Van Wee, 2002; Giuliano, 2004; Schmeidler, 2008; Adamiak et al., various facilities (Rudnicki, Wojnar, 2009; Kim, Susilo, 2013; Romanowska, Jamroz, 2013; Szarata, 2013). By adapting the local mobility determinants - such as the road and street network, the level of motorisation, and the local functional and spatial infrastructure - as 'the background' of the analysis, one can show the volume of trips taken by vehicles using this part of the urban road network which is monitored in the areas where selected elements of the city's spatial structure are present.

The data used in the research does not substitute information on travel motivation, starting points and destinations, collected directly from road users. It only presents the load of the network which is - to 
a certain extent - a snapshot of the choices made by road users at any given time. Thus, this research is of a general nature - i.e. holistic - since it incorporates all movement without discussing individual dimensions of mobility. Therefore, any conclusions should not be treated as accurate indications, but as certain issues which ought to be perceived as a contribution to and incentive for further sectoral analyses related to traffic generation of individual elements within the functional and spatial structure, and mobility in urban networks (Kowalski, Wiśniewski, 2017a).

Regardless of the difficulties mentioned above, the data from the RTCS system, based on measurements of road traffic loads taken by means of induction loops, is quite valuable. The analyses conducted on its basis and related to the comparison of traffic load in the space characterised by a diverse functional and spatial structure make it possible to draw general conclusions. Traffic volume within the structure of a big city is - to a certain extent (depending on the local characteristics of the transport network, with particular focus on its internal elements of systems of intra- and extra-urban transit) - conditioned by the deployment of inhabitants and spheres of various functionalities (Fig. 7), and the elements of transportation systems that link them (including the availability of substitutive means of transport to the car, and the vicinity of transit arteries) and the factors that stem

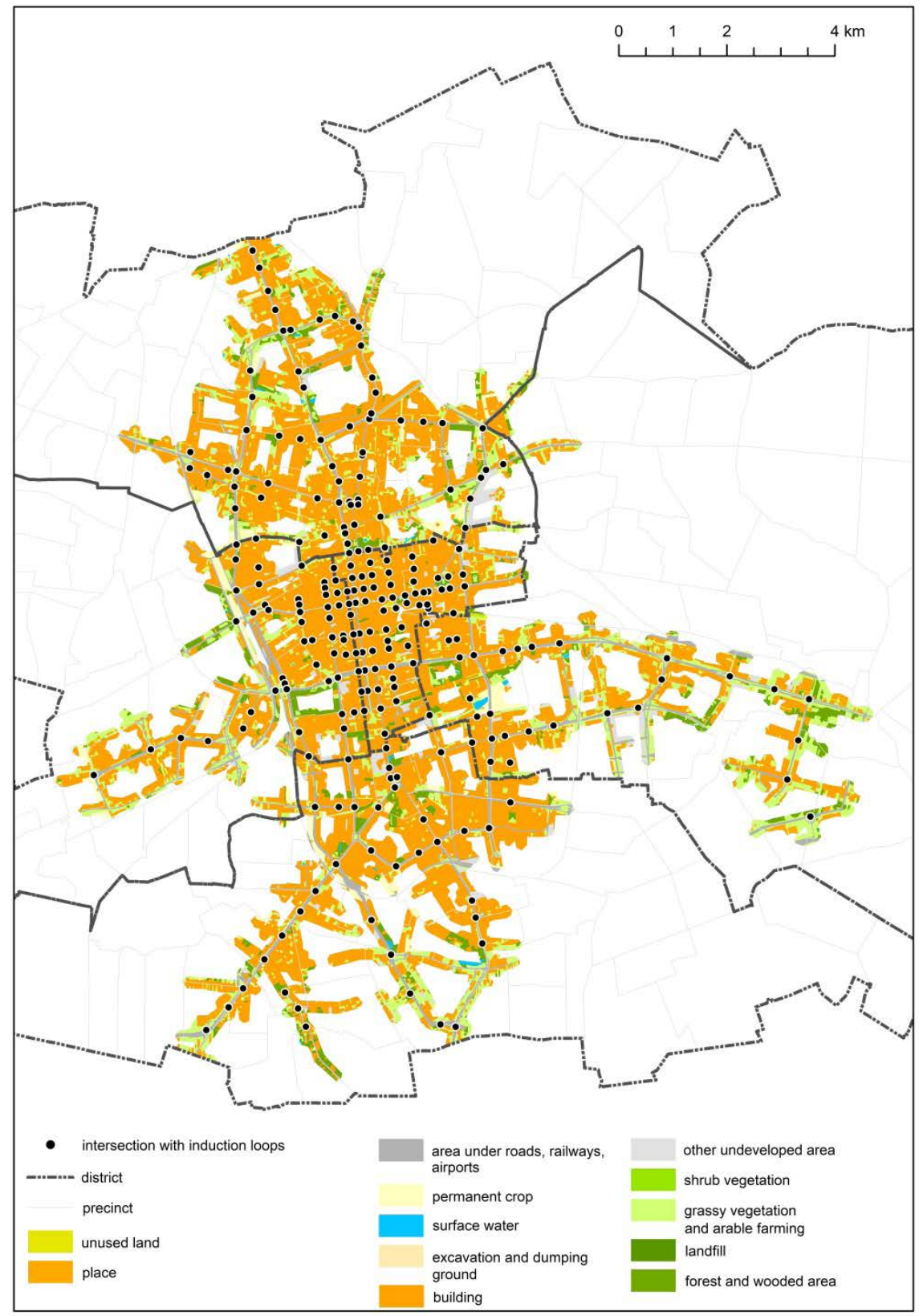

Fig. 6. Spatial management in Lodz around intersections with RTCS induction loops.

Source: authors' own elaboration, Kowalski M., Wiśniewski S., 2017a. 
from road users' transport behaviours and the level of motorisation.

Therefore, without the possibility of separating the traffic flows which are connected with transit (including extra-urban transit), it is impossible to present the traffic generation of facilities on the scale of the whole city. In this context, the most crucial value

\section{Automatic Number Plate Recognition Cameras}

Enabling the optical recognition of characters, this technology is used for the automatic reading of number plates in order to generate data on the location of any given vehicle (Patel et al., 2013). It may be based
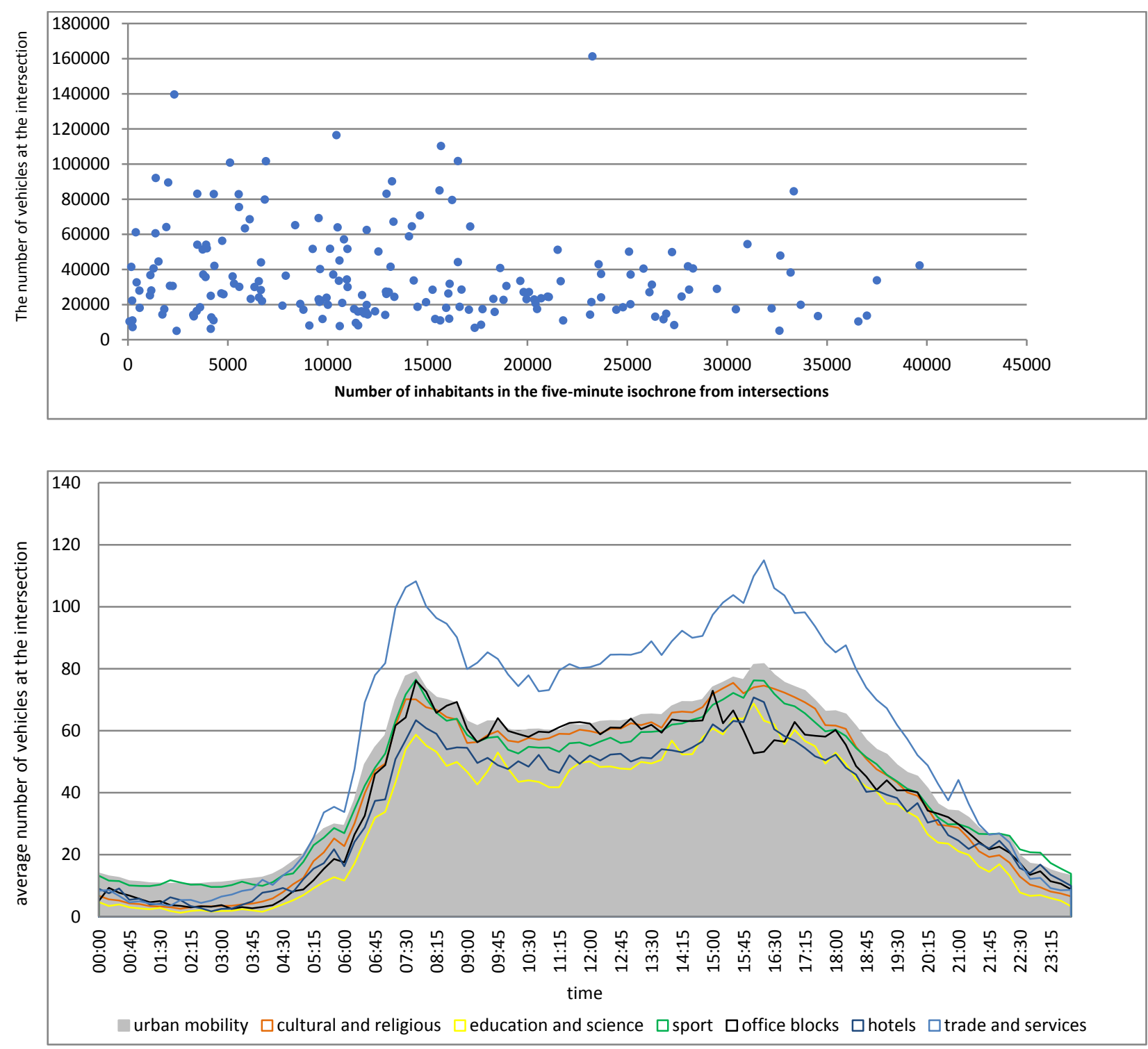

Fig. 7. Traffic density versus population within five-minute isochrones from monitored intersections (top) and in the vicinity of selected public facilities (bottom).

Source: authors' own elaboration, Kowalski M., Wiśniewski S., 2017a.

of the presented research is the representation, on a local scale, of the travel volume in the areas where any given type of management or functionality is present, and linking it to its deployment within the urban transportation network. on existing CCTV, surveillance cameras or devices which have been designed specifically for this purpose (Kulkarni et al., 2009). The ANPR system is used by various services to execute the law, e.g. to verify if any given vehicle is legally registered. It is also 
used for electronic toll collection and as a method of cataloguing movements of vehicles, their routes and travel times (Rhead et al., 2012). The functioning of ANPR analyses is the subject of studies conducted by representatives of numerous branches, including transport engineers (Bodger et al., 2005; Dix, Firth, 2005; Slinn et al., 2006; Matysiak et al., 2013; Robinson, 2014; Robinson, Van Niekerk, 2014), electronic engineers (Kulkarni et al., 2009; Qadri, Asif, 2009; Gaikwad, Borole, 2014; Kumar et al., 2017), and experts in image analysis and recognition (Anagnostopoulos et al., 2008; Patel et al., 2013; Janowski et al., 2014; Kaur, Kaur, 2014). And since there are still relatively few geographical studies derived from the area of ANPR, it seems justified to emphasise the potential of data provided by this constituent of the ITS system.

The system saves and stores information from ANPR cameras in the form of a database, where each row refers to a single registration of a number plate by any given camera. Having formulated a query to the database (e.g. selecting those rows which were saved within a specified period of time), the researcher is returned with a source file in a text format. Once it has been converted into a table within a spreadsheet (Tab. 2), further analyses are possible, based on data aggregation or sorting. The researcher is presented with the data on a record number, a precise date and time when any given photo was taken by the camera, the ID number of the camera and the intersection where it is installed, geographic coordinates of the camera, the country in which any given vehicle is registered, and its number plate. Here, it becomes imperative to discuss the issue of privacy law related to the acquisition of this type of data for scientific and research purposes. This issue primarily depends on the statutory interpretation in this regard, but also on the interpretation - individual for each case - applied by civil servants who are the legal custodians of ANPR data. In this particular case, the number plate was considered to be sensitive information (in the light of the Personal Data Protection Act), and thus, it was encrypted by means of a string of several dozen characters. Fortunately, each number plate is coded with a unique, permanently ascribed string of characters, and thus it is still possible to 'track' the vehicle.

Although the initial format of the database is clearly extremely valuable research material, its worth is even greater once it has been formatted into a database that demonstrates vehicle movement. In its initial form, the identification of this phenomenon is stymied mainly due to its volume (in the case of the discussed example, it contains approximately 6 million photographs for a period of one week), but also due to the necessity of simultaneous data sorting and aggregation with regard to two features: the registration number and the accruing time. Therefore, it becomes imperative to prepare a simple tool (in any programming language), which will automatize the processing of the source database into a relational one (Tab. 3).

The key data within the generated table is the information on the spots where all subsequent photographs of the same vehicle were taken and the time that passed between taking them. Thus it is possible to track the route taken by each vehicle individually, though only, of course, within the range of the area covered by ANPR cameras. It must, however, be remembered that travelling between cameras does not necessarily entail direct movement between these spots within the city space. These may be points lying along the route of two completely different vehicles. Therefore, it is not inconceivable either that a vehicle may be recorded by the system only on January 1 and December 31 of the same year, and thus its record in the database will show a transit across the city that lasted approximately 31 million seconds. Though this case requires a careful interpretation of the results, use of this kind of data does open new fields of exploitation and reasoning. What again manifests itself here is the lack of qualitative travel data, e.g. information on destinations. One may only attempt to obtain this type of data in an indirect manner, e.g. by analysing the vicinity of ANPR cameras. With so few research spots, however, drawing any conclusions is very risky. In the relational database, there are also rows which show a single registration of a vehicle within the system (the starting point and destination are the same and the travel time equals zero). These are vehicles which were recorded by only one camera within the system (Fig. 8). Together with an increase in the range of time of the database, the relative number of such cases should decrease, since - in the course of time - the probability of another registration by other cameras of the ITS system grows. There are also instances when a record in the relational database indicates a complete lack of movement in space (the same starting and finishing point), but there is movement in time. This can happen when the daily movement of any given vehicle user is performed within the borders of the same district which is covered by a single ANPR camera. Even though there is a series of movements, they are all recorded by only one device. 


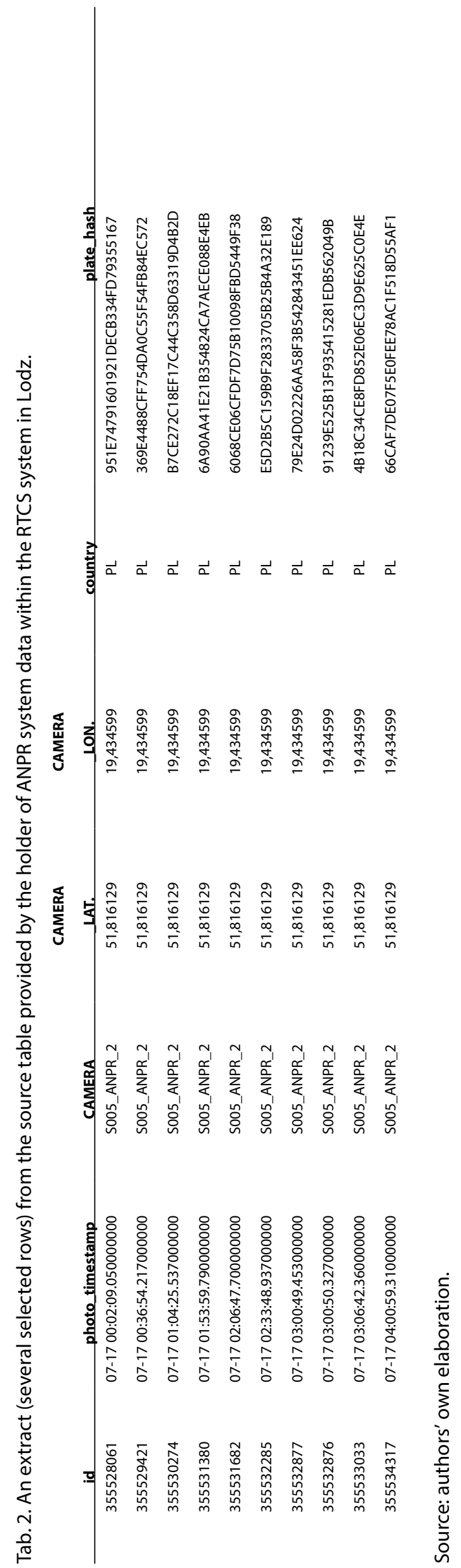

मี้

兽售

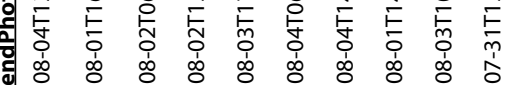

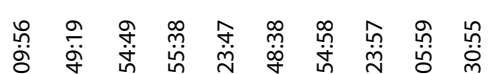

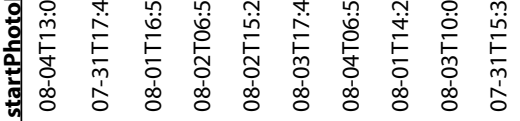

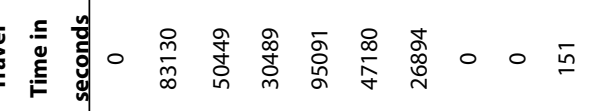

है

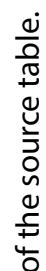

政高

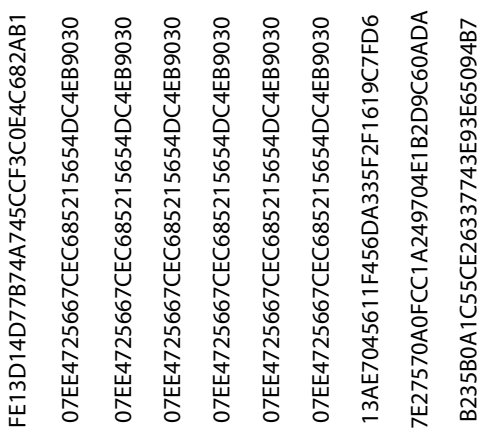

$\frac{n}{\sqrt{0}}$

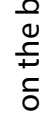

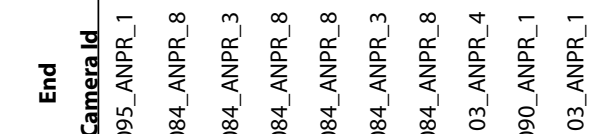

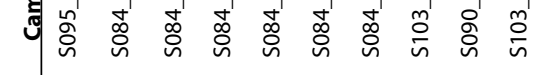

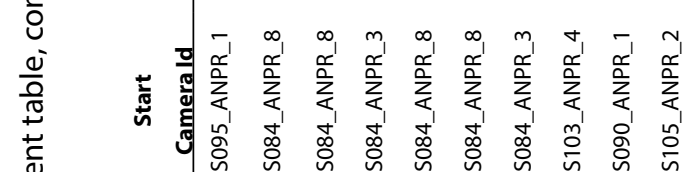

离

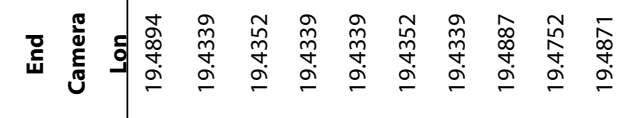

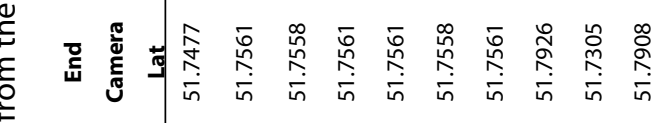

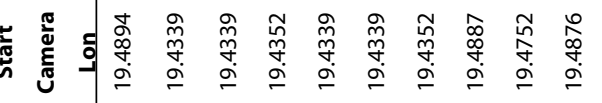




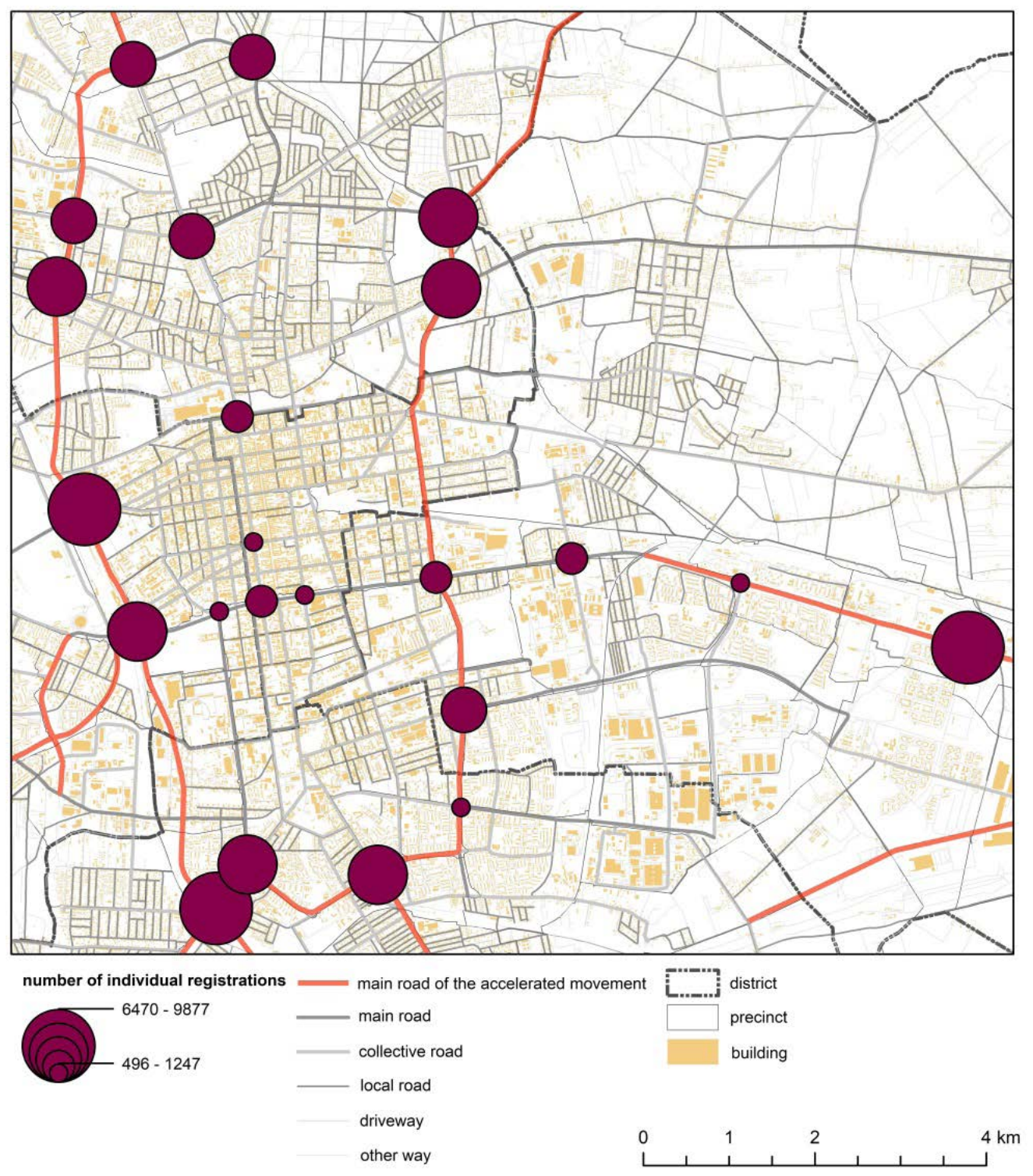

Fig. 8. The number of individual vehicles registered by ANPR cameras within the RTCS system in Lodz during a 24-hour period.

Source: authors' own elaboration.

Just as in the case of the aforementioned data from induction loops, the material generated by the ANPR system may be used directly - as purely informative data - or for the purposes of problem analyses. The former involves the indication of basic characteristics of a group of vehicles registered by the system (Fig. 9) in the form of, for instance, spatial and time differentiation of the number of vehicles registered by cameras (or aggregated to intersections) (Fig. 10).

Working on relational data renders it possible to generate a map of traffic structure, where individual ANPR cameras are taken as starting points and destinations (Fig. 11). It also enables us to track and present the travel path of any given vehicle (Fig. 12). Other valuable data which can be useful to analyse the efficiency of an urban transportation system is information on the number of vehicles travelling between cameras within one intersection and their travel times in the said area. This will make it possible, for instance, to determine whether the applied timing of signal phases at traffic lights corresponds with the traffic density occurring at any exit and the vehicle flows that are actually served by any given intersection. Such analyses are of invaluable importance to transport engineers. 


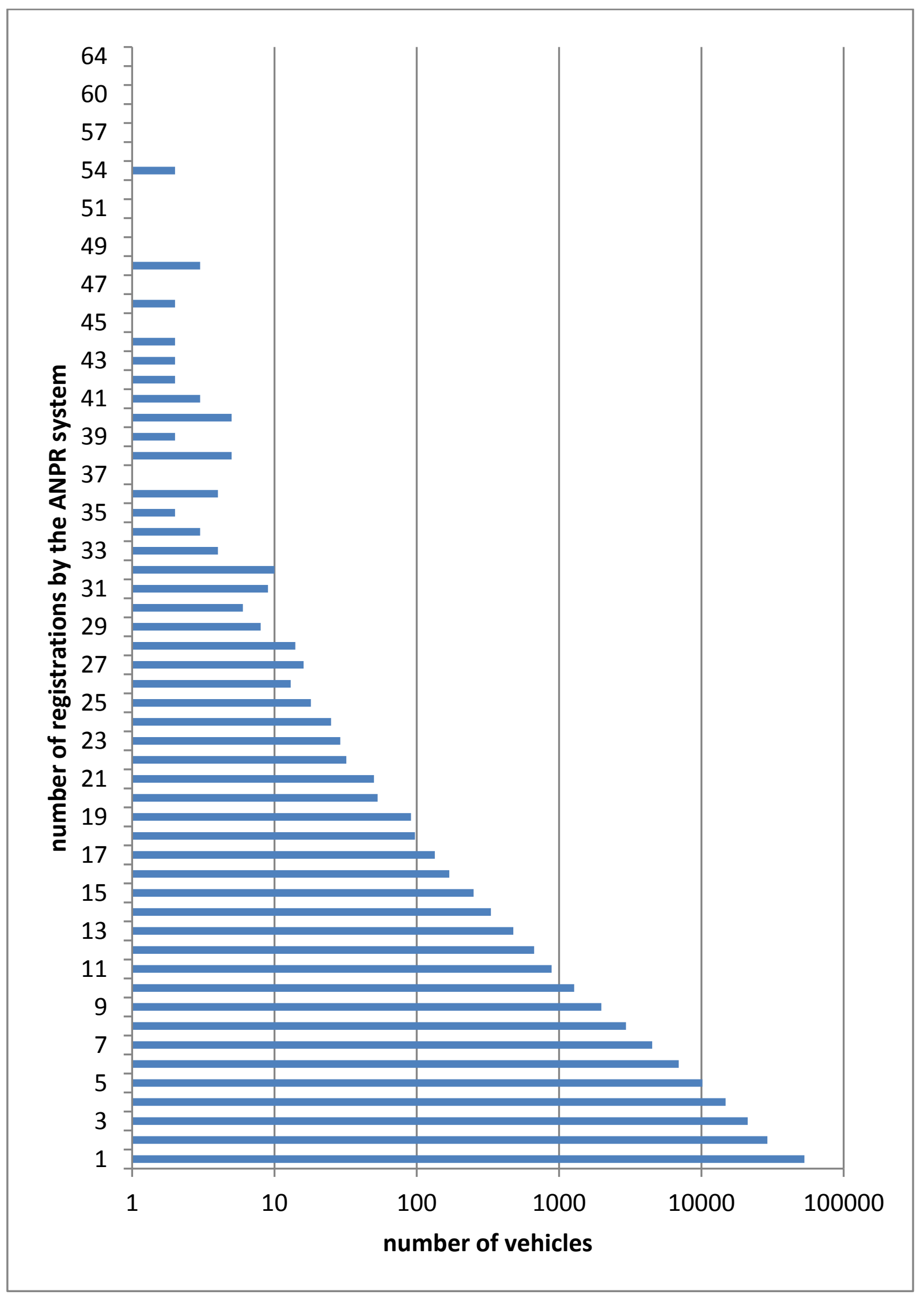

Fig. 9. The number of vehicles registered by the ANPR system within the RTCS system in Lodz during a 24 - hour period. Source: authors' own elaboration. 


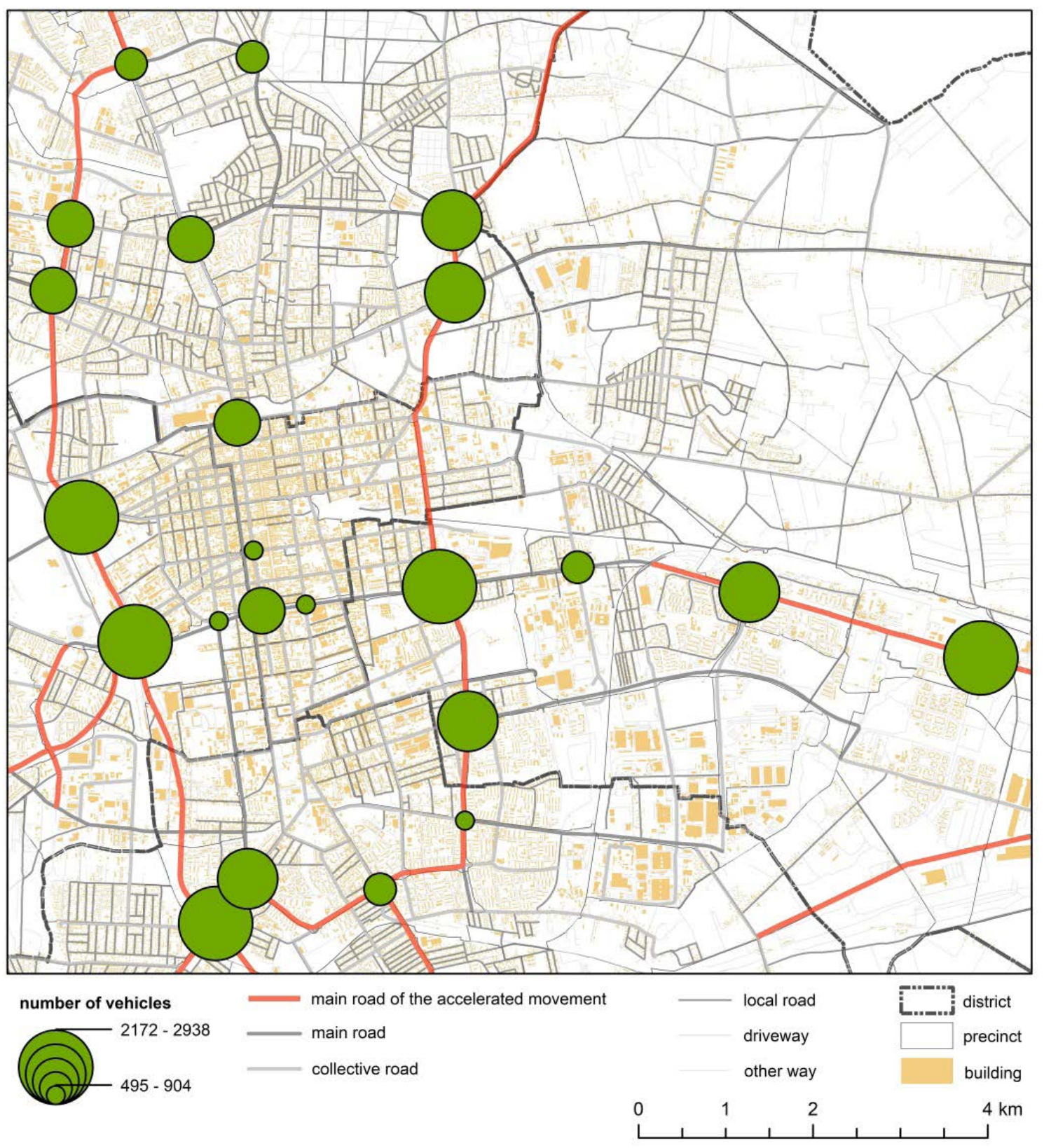

Fig. 10. The number of vehicles registered by the ANPR system within the RTCS system in Lodz during a morning rush hour.

Source: authors' own elaboration. 


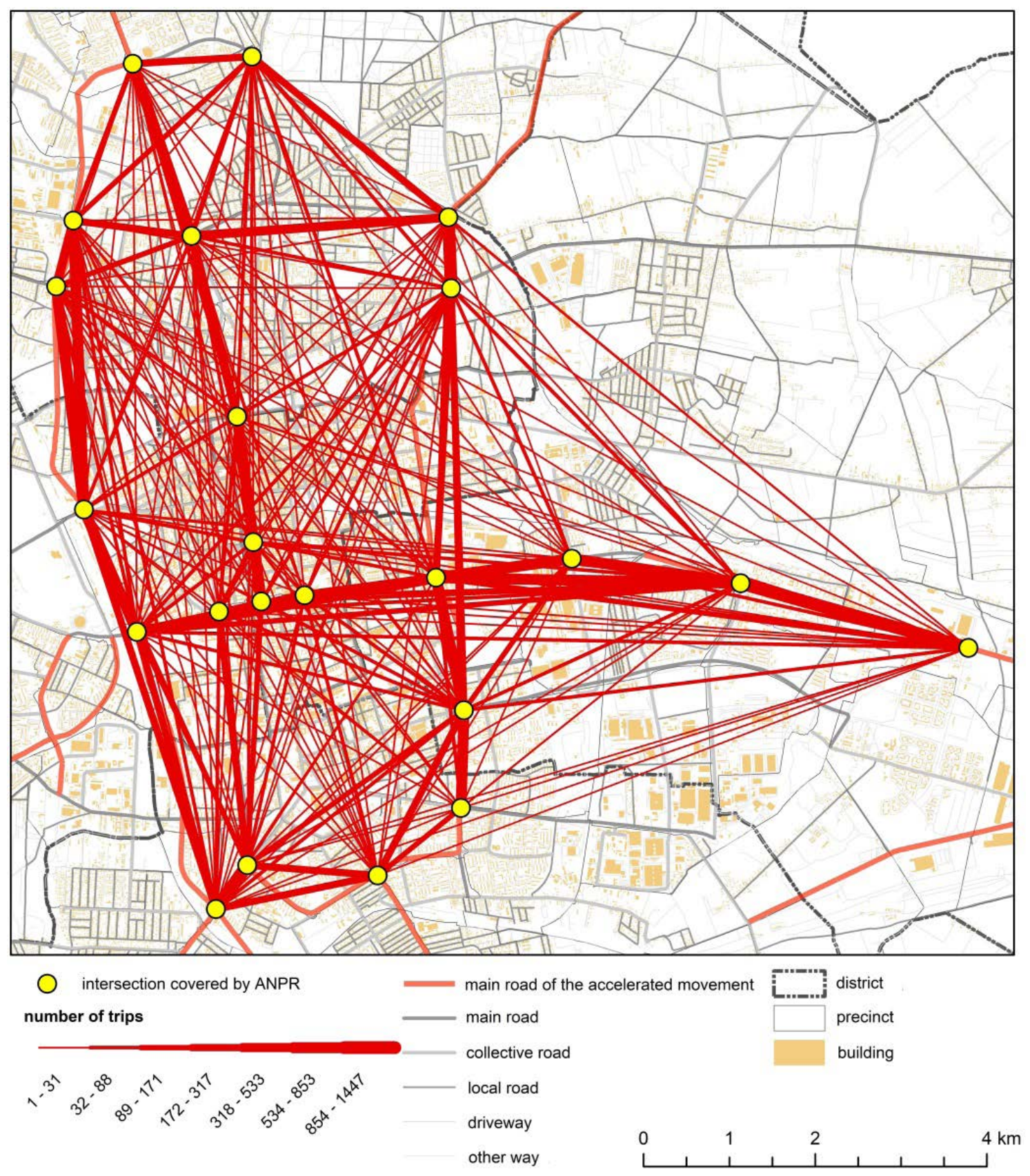

Fig. 11. The number of transits registered by ANPR cameras within the RTCS system in Lodz during a morning rush hour.

Source: authors' own elaboration. 


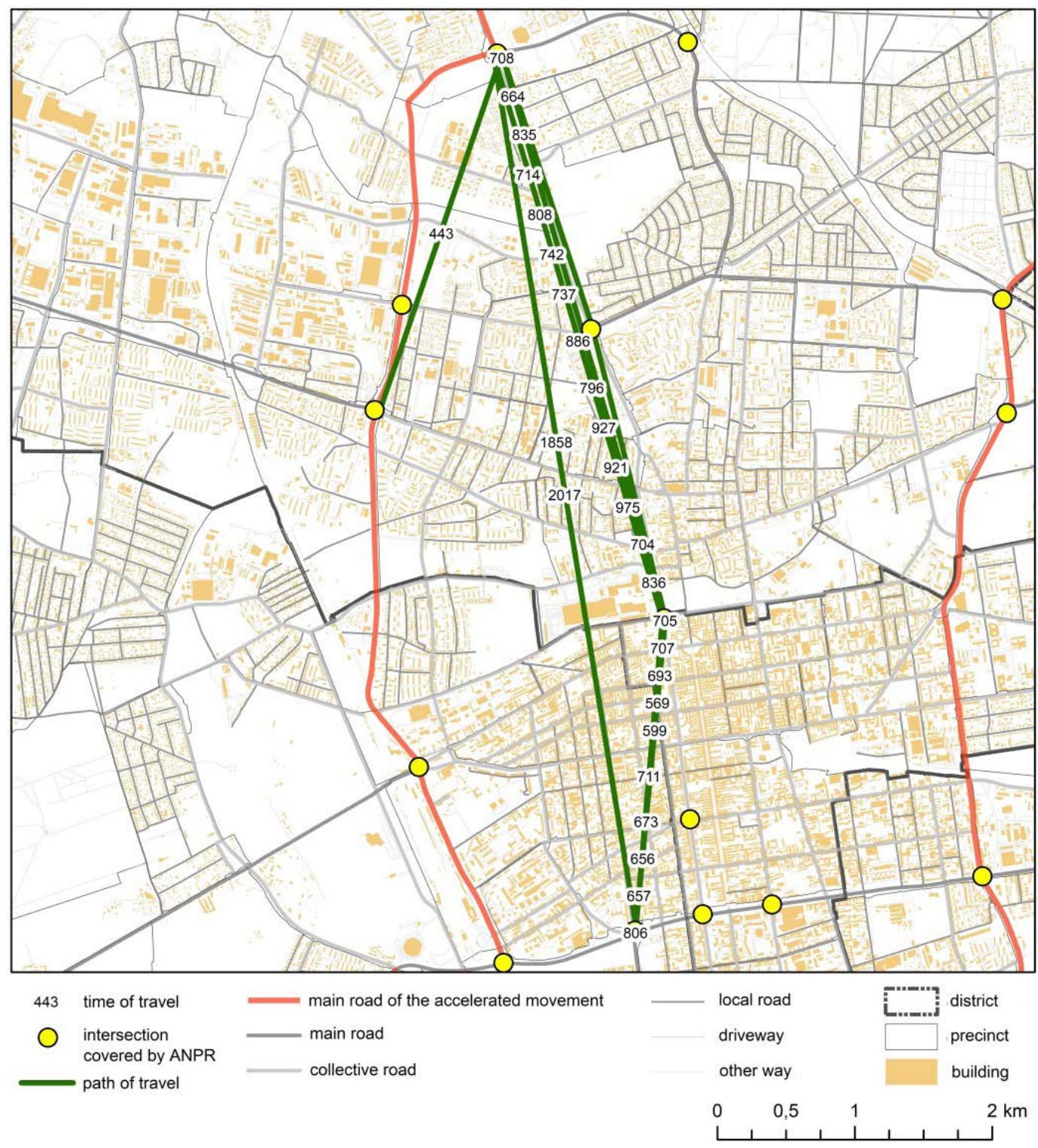

Fig. 12. The traffic structure for one of the vehicles registered by ANPR cameras within the RTCS system in Lodz during one day.

Source: authors' own elaboration.

The data from the ANPR system possesses, above all, great potential as research material for the purposes of a broad spectrum of problem analyses related to the urban subsystem of road transportation. It allows studies aimed at the identification of the city's internal transit, i.e. determining the features of the movement of vehicles which only pass through a selected area within the city (e.g. the city centre). Naturally, the possibility of conducting this type of analysis is determined by the appropriate deployment of registration devices. In the light of the global trend to decrease the density of traffic related to private car use in city centres (Szendro,
2011), it is possible to analyse numerous phenomena which may greatly facilitate the implementation of such policies. It is possible to identify the significance of the city centre in transits between specified areas of the city by researching how often it becomes an intermediate point on the route taken to reach any given destination. A detailed analysis of ANPR data also gives grounds for reasoning on the issue of halt time, and more generally, on the time vehicles spend in any given part of the city, which is a crucial indicator in planning an effective parking policy within the city or designing tariff systems for public transport. 
Analysing the database of flows with an appropriately broad time range makes it possible to identify various types of shuttle trips, such as commuting. A longer analytical period also reveals transit traffic in the whole city. And this is extremely valuable data for the process of evaluating infrastructural investments in progress, studies on changes in communication behaviours related to, for example, restrictions in trade, and analyses of the influence of changes in traffic organisation and management (related to sporting events, concerts, etc.), since it offers accurate comparative material for the situation before and after the implementation of the research subject.

The data generated by an ANPR system is also indispensable material for studies devoted to the comparison of theoretical (i.e. concordant with traffic laws and regulations) and actual travel time on various segments of the urban network of roads and streets (Fig. 13). It is a valuable alternative to travel times (applied, for instance, in methodology of accessibility analyses) and historical and real-time data provided by different types of online navigation services (e.g. Google Maps' Google Traffic).

The presented data can also be part of the process of traffic modelling for a city's road network (Fig. 14). Traffic modelling and forecasting is a relatively new but dynamically developing branch of science, closely related to the issue of planning transportation systems (Dybicz, 2009). Over the years, miscellaneous methodological approaches have been taken, but recently researchers are more and more likely to apply models which substitute the first three stages of the classical traffic model. These are models based on the inhabitants' travel activity. Unfortunately, their application is connected with a drastic increase in expenditure on research of communication behaviours and preferences, which, however, can be solved by the use of data obtained from an ITS system (naturally, with all the aforementioned simplifying assumptions in mind). The generation of traffic models for cities and larger agglomerations allows numerous analyses to be conducted, which are crucial for the assessment of the existing state of affairs and future planning, including analyses of traffic conditions, transport intensity and infrastructural needs, analyses of the environment, noise, emissions, the impact of changes in spatial management upon the transportation system, and the influence of demographic and economic changes, transportation policy and efficiency of projects for infrastructural development (Dybicz, 2009).
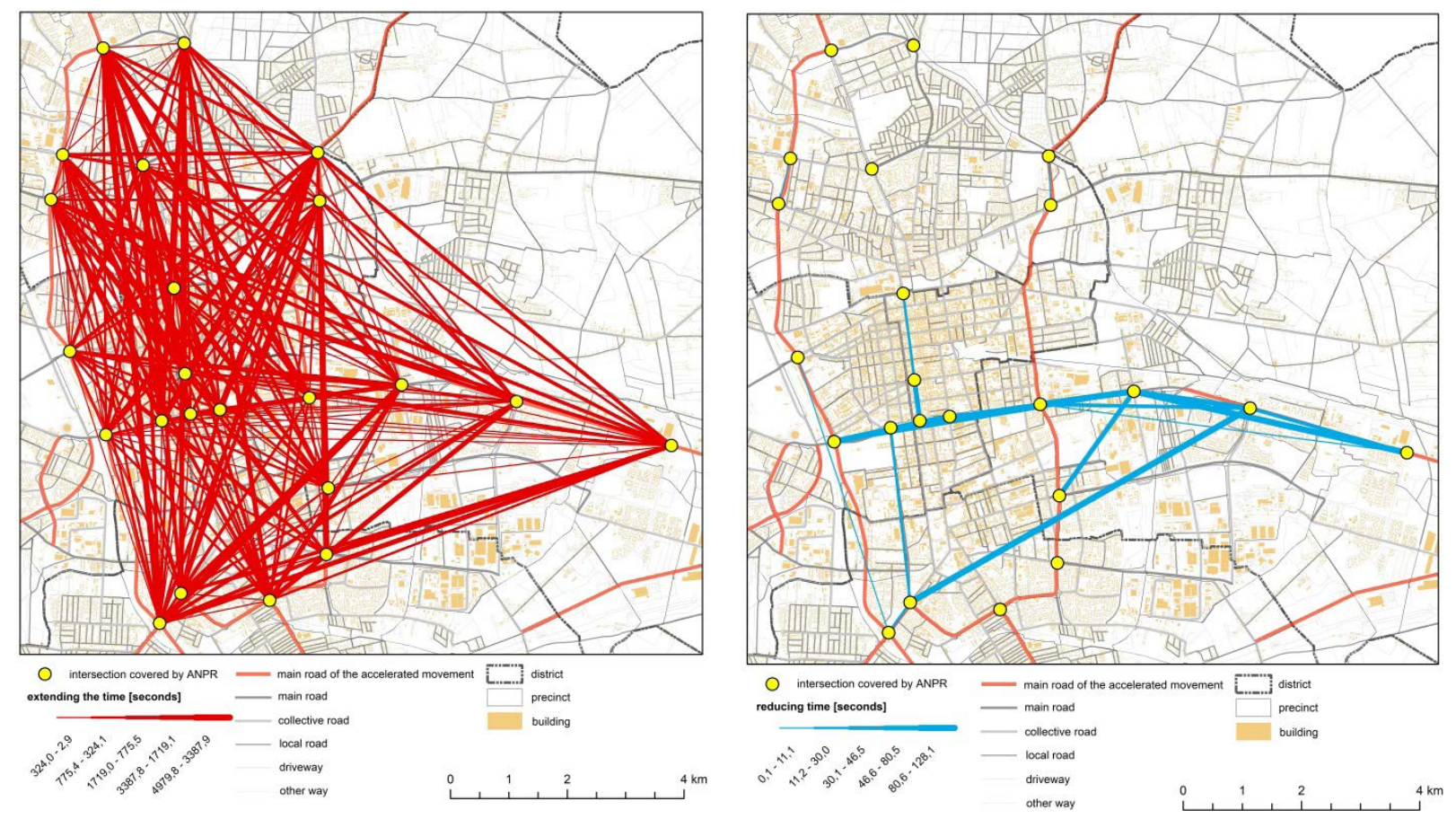

Fig. 13. Shorter (A) and longer (B) transits during a morning rush hour in Lodz, when compared to a theoretical travel time.

Source: authors' own elaboration. 


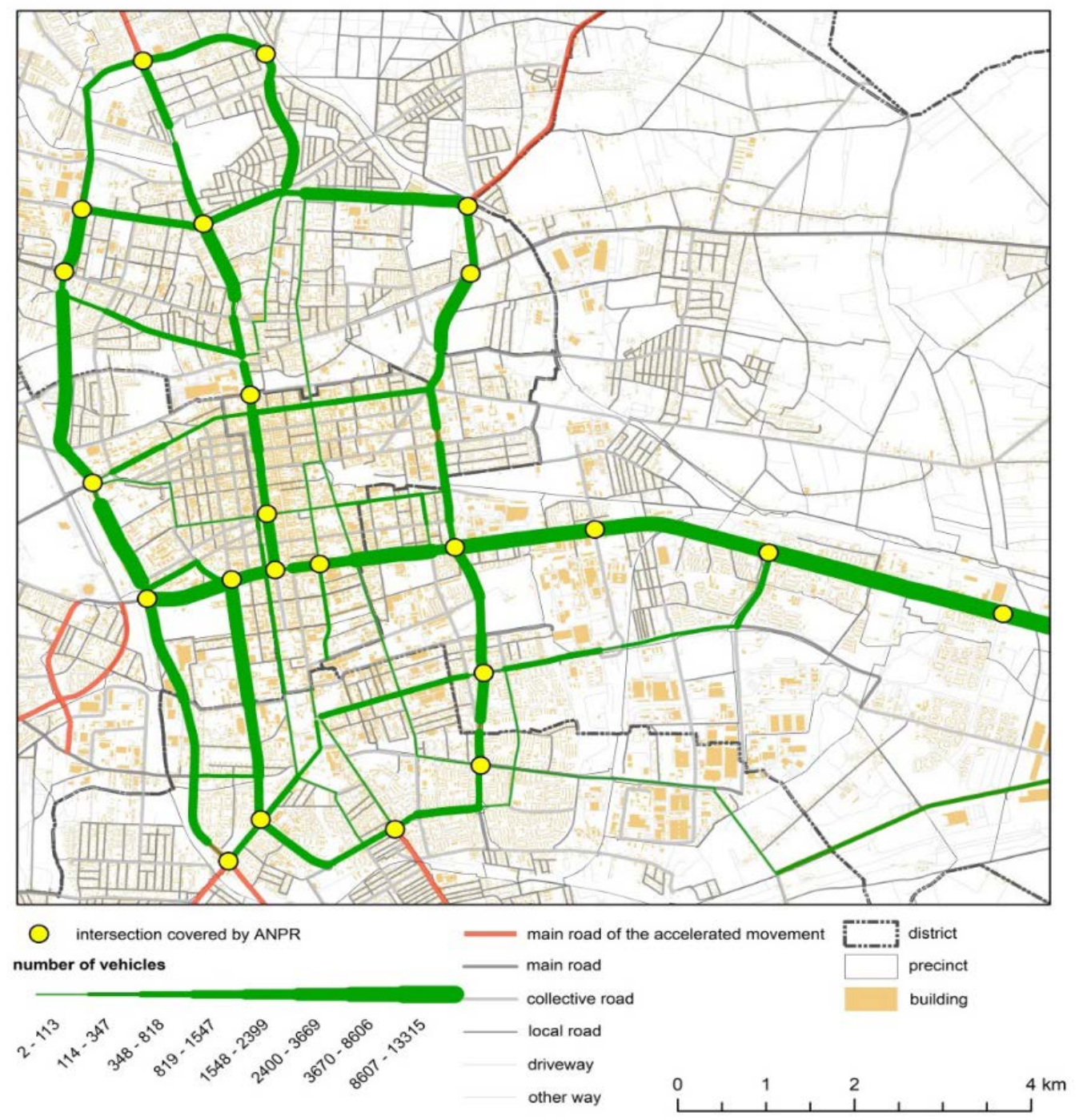

Fig. 14. Distribution of vehicle traffic registered by ANPR cameras within the RTCS in Lodz during a morning rush hour across the road network.

Source: authors' own elaboration.

\section{Conclusions}

Research on human spatial mobility in a city is a prerequisite of any transportation and spatial policy if it is to be appropriately implemented by local authorities. Since such studies are very expensive and timeconsuming, their frequency does not correspond with the revolutionary and radical transformations in people's mobility. Thus, there is a natural need for alternative data sources with a similar profile, one of which is the Intelligent Transportation System with the data it collects and generates, and which should no longer remain unused. Although the deficiency of this data in mobility studies is rather obvious and has been clearly presented in this article, it still offers a series of properties that a researcher cannot obtain from any other source. Nevertheless, any work on the presented data must be conducted with the utmost care, especially as far as conclusions are concerned. An optimum solution would be to combine this data with results of standard research on spatial mobility. Firstly, it would allow us to verify the accuracy of the data and to determine the level of importance for the sample covered by the ITS system, but - above all - it would expand the holistic picture of data with features that are crucial for mobility studies but are not provided by the ITS system alone, i.e. reasons for travelling. Work on the data retrieved from induction loops and ANPR cameras must also be performed by a researcher who is well aware of the unique nature of the urban transportation system in question and the principles of how these measuring devices work, since an uncritical approach may result in a significantly distorted image of reality. Another major issue in this 
matter is the structure of the ITS system itself, and more precisely, the number and deployment of measuring devices in relation to the spatial management of the city. Naturally, a small number of devices deployed over a relatively small area still allows research, but the decision to refer the returned results to the whole area of the city must not be made without a prior and thorough consideration, since transportation behaviours typical in the city centre are unlikely to be reflected in the suburbs. What is more, the lack of coverage of certain regions within the city renders it impossible to perform certain types of problem analyses.

The result of the shown research, apart from presenting some aspect of mobility, also demonstrates that ITS data can be used in geographical studies, with an indication that it is imperfect in the context of a more global study on mobility in the relatively complex structure of a big city.

\section{Acknowledgment}

This paper was produced under the research projects no. 2019/33/N/HS4/01733 and 2019/35/D/HS4/00697, financed from the funds of the National Science Centre in Poland.

\section{References}

Albert G., Mahalel D., 2006, Congestion tolls and parking fees: A comparison of the potential effect on travel behavior, Transport Policy, 13(6), 496-502.

Ambak K., Atiq R., Ismail R., 2009, Intelligent transport system for motorcycle safety and issues, European Journal of Scientific Research, 28(4), 600-611.

Anagnostopoulos C.N.E., Anagnostopoulos I. E., Loumos V., Kayafas E., 2006, A license plate-recognition algorithm for intelligent transportation system applications. IEEE Transactions on Intelligent transportation systems, 7(3), 377-392.

Anagnostopoulos C.N.E., Anagnostopoulos I. E., Psoroulas I.D. Loumos V., Kayafas E., 2008, License plate recognition from still images and video sequences: A survey. IEEE Transactions on intelligent transportation systems, 9(3), 377-391.

Badoe D.A., Miller E.J., 2000, Transportation-land-use interaction: empirical findings in North America, and their implications for modeling, Transportation Research Part D: Transport and Environment, 5(4), 235-263.

Barceló J., Casas J., Ferrer J.L., García D., 1999, Modelling advanced transport telematic applications with microscopic simulators: The case of AIMSUN2. In Traffic and Mobility, Springer, Berlin-Heidelberg, 205-221.

Barwiński S., Kotas P., 2015a, Inteligentne Systemy Transportowe jako narzędzie rozwiązywania problemów komunikacyjnych miast na przykładzie Łodzi, [w:]
W. Grzegorczyk (red.) Wybrane problemy zarządzania i finansów. Studia przypadków, Wydawnictwo Uniwersytetu Łódzkiego, Łódź.

Barwiński S., Kotas P., 2015b, Inteligentne Systemy Transportowe w wybranych miastach Polski, Autobusy: Technika, Eksploatacja, Systemy Transportowe, 16, 26-29.

Bazzan A.L.C., Klügl F., 2014, Introduction to Intelligent Systems in Traffic and Transportation, Morgan \& Claypool.

Bertolini L., Le Clercq F., Kapoen L., 2005, Sustainable accessibility: a conceptual framework to integrate transport and land use plan-making. Two test-applications in the Netherlands and a reflection on the way forward. Transport Policy, 12(3), 207-220.

Biswas S., Tatchikou R., Dion F., 2006, Vehicle-to-vehicle wireless communication protocols for enhancing highway traffic safety. IEEE communications magazine, 44(1), 74-82.

Boarnet M.G., Sarmiento S., 1998, Can land-use policy really affect travel behaviour? A study of the link between non-work travel and land-use characteristics, Urban Studies, 35(7), 1155-1169.

Boarnet M.G., 1996, The direct and indirect economic effects of transportation infrastructure. Working Paper No. 340, University of California Transportation Center, Berkeley.

Bodger M., Ellison J., Paramer J., 2005, Developing journey time performance indicators for the urban environment using ANPR technology, Traffic Engineering \& Control, 46(9).

Buch N., Velastin S.A., Orwell J., 2011, A review of computer vision techniques for the analysis of urban traffic, IEEE Transactions on Intelligent Transportation Systems, 12(3), 920-939.

Burnos P., Gajda J., Marszałek Z., Piwowar P., Sroka R., Stencel M., Żegleń T., 2011, Road traffic parameters measuring system with variable structure, Metrology and Measurement Systems, 18(4), 659-666.

Burnos P., Gajda J., Piwowar P., Sroka R., Stencel M., Żegleń T., 2007, Accurate weighing of moving vehicles. Metrology and Measurement Systems, 14(4), 507-516.

Campbell M., Egerstedt M., How J.P., Murray R.M., 2010, Autonomous driving in urban environments: approaches, lessons and challenges, Philosophical Transactions of the Royal Society of London A: Mathematical, Physical and Engineering Sciences, 368(1928), 4649-4672.

Ciastoń-Ciulkin A., 2014, Zrównoważona mobilność mieszkańców obszarów zurbanizowanych, Autobusy: Technika, Eksploatacja, Systemy Transportowe, 15, 14-20.

Costabile F., Allegrini I., 2008, A new approach to link transport emissions and air quality: An intelligent transport system based on the control of traffic air pollution, Environmental Modelling \& Software, 23(3), 258-267.

Dąbrowska-Loranc M., Leśniowska-Matusiak I., 2011, Programy edukacyjne a mobilność użytkowników dróg, Transport Miejski i Regionalny, (1), 19-23.

Dix M., Firth D., 2005, Transport for London Congestion Charging--Scheme Developments and the Use of New 
Technology. In 12th World Congress on Intelligent Transport SystemsITS AmericalTS JapanERTICO.

Du H., Mulley C., 2006, Relationship between transport accessibility and land value: Local model approach with geographically weighted regression, Transportation Research Record: Journal of the Transportation Research Board, 1977, 197-205.

Dudek P., Ochelska-Mierzejewska J., 2016, Analiza wybranych czynników wpływających na jakość komunikacji miejskiej w Łodzi ze szczególnym uwzględnieniem transportu tramwajowego, Autobusy: Technika, Eksploatacja, Systemy Transportowe, 17(12), 590-597.

Dybicz T., 2009, Modelowanie i symulacje ruchu, rys historyczny i aktualnie stosowane oprogramowanie. Zeszyty Naukowo-Techniczne Stowarzyszenia Inżynierów i Techników Komunikacji w Krakowie. Seria: Materiały Konferencyjne, 90, 148, 57-73.

Eisner R., 1991, Infrastructure and regional economic performance: comment, New England Economic Review, Sep, 47-58.

Elhorst J.P., Oosterhaven J., 2002, Effects of transport improvements on commuting and residential choice, Technical report, Mimeo, University of Groningen, NL.

Filjar R., Dujak M., Drilo B., ŠariC D., 2009, Intelligent transport system. recent advancements provide means for exploitation of mobile user location-related data for location-based and its services.

Gaikwad D.Y., Borole P.B., 2014, A Review Paper on Automatic Number Plate Recognition (ANPR) System, International Journal of Innovative Research in Advanced Engineering (IJIRAE) Volume, 1.

Gajda J., Sroka R., Stencel M., Wajda A., Zeglen T., 2001, May, A vehicle classification based on inductive loop detectors, [w:] Instrumentation and Measurement Technology Conference, 2001. IMTC 2001. Proceedings of the 18th IEEE, 1, 460-464.

García C.R., Quesada-Arencibia A., Cristóbal T., Padrón G., Alayón F., 2016, Systematic development of intelligent systems for public road transport, Sensors, 16(7), 1104.

Gerla M., Lee E.K., Pau G., Lee U., 2014, March, Internet of vehicles: From intelligent grid to autonomous cars and vehicular clouds. [w:] Internet of Things (WF-loT), 2014 IEEE World Forum on, 241-246.

Geurs K.T., Van Wee B., 2004, Accessibility evaluation of land-use and transport strategies: review and research directions, Journal of Transport Geography, 12(2), 127-140.

Giuliano G., 2004, Land use impacts of transportation investments, The Geography of Urban Transportation, 3, 237-273.

Givoni M., 2006, Development and impact of the modern high-speed train: A review, Transport Reviews, 26(5), 593-611.

Hagman O., 2006, Morning queues and parking problems. On the broken promises of the automobile, Mobilities, $1(1), 63-74$.
Halden D., 2002, Using accessibility measures to integrate land use and transport policy in Edinburgh and the Lothians, Transport Policy, 9(4), 313-324.

Harmatuck D.J., 1996, The influence of transportation infrastructure on economic development, Logistics and Transportation Review, 32 (1), 63-76.

Heath G.W., Brownson R. C., Kruger J., Miles R., Powell K.E., Ramsey L.T., Task Force on Community Preventive Services, 2006, The effectiveness of urban design and land use and transport policies and practices to increase physical activity: a systematic review, Journal of Physical Activity and Health, 3(s1), S55-S76.

Janowski L., Kozłowski P., Baran R., Romaniak P., Glowacz A., Rusc T., 2014, Quality assessment for a visual and automatic license plate recognition, Multimedia Tools and Applications, 68(1), 23-40.

Jirón P., 2009, Mobility on the move: Examining urban daily mobility practices in Santiago de Chile, London School of Economics and Political Science (United Kingdom).

Jones P.M., Dix M.C., Clarke M.I., Heggie I.G., 1983, Understanding travel behaviour (No. Monograph).

Kaufmann V., Bergman M.M., Joye D., 2004, Motility: mobility as capital, International Journal of Urban and Regional Research, 28(4), 745-756.

Kaur S., Kaur S., 2014, An efficient approach for number plate extraction from vehicles image under image processing, International Journal of Computer Science and Information Technologies, 5(3), 2954-2959.

Kim N.S., Susilo Y.O., 2013, Comparison of pedestrian trip generation models, Journal of Advanced Transportation, 47(4), 399-412.

Kitamura R., Mokhtarian P.L., Laidet L., 1997, A micro-analysis of land use and travel in five neighborhoods in the San Francisco Bay Area, Transportation, 24(2), 125-158.

Kochanowska M., 2011, Wstępny plan mobilności dla pracowników Biura Drogownictwa i Komunikacji Urzędu Miasta Warszawy, Transport Miejski i Regionalny, 24-27. Kockelman K., 1997, Travel behavior as function of accessibility, land use mixing, and land use balance: evidence from San Francisco Bay Area, Transportation Research Record: Journal of the Transportation Research Board, (1607), 116-125.

Kowalski M., Wiśniewski S., 2017a, Natężenie ruchu a zagospodarowanie Łodzi - zarys problematyki w świetle danych z Obszarowego Systemu Sterowania Ruchem, Prace Komisji Geografii Komunikacji PTG, 20 (4), 20-36.

Kowalski M., Wiśniewski S., 2017b, Centrum handlowe jako czynnik ruchotwórczy w transporcie samochodowym - przykład Portu Łódź (A shopping centre as a traffic-generating factor In car transport as exemplified by Port Łódź, Poland), Przegląd Geograficzny, 89(4), 617-639. Koźlak A., 2008, Inteligentne systemy transportowe jako instrument poprawy efektywności transportu, Logistyka, 2 (artykuł opublikowano na CD będącym integralną częścią czasopisma). 
Kraft S., 2014, Daily spatial mobility and transport behaviour in the Czech Republic: pilot study in the Písek and Bystrice and Pernstejnem regions, Human Geographies, 8(2), 51.

Kulkarni P., Khatri A., Banga P., Shah K., 2009, April, Automatic number plate recognition (ANPR) system for indian conditions, [w:] Radioelektronika, 2009. RADIOELEKTRONIKA'09. 19th International Conference, 111-114.

Kumar K.K., Sailaja V., Khadhee, S., Viswajith K., 2017, Automatic Number Plate Recognition System, Indian Journal of Science and Technology, 10(4).

Li J., Van Zuylen H.J., Wei G., 2014, Loop detector data error diagnosing and interpolating with probe vehicle data, [w:] 93rd Annual Meeting Transportation Research Board, Washington, USA, 12-16 January 2014; Authors version, TRB.

Li Y., Li Z., 2008, Grey Relational Analysis between Infrastructure Investment and Economic Growth in China from 1997 to 2006, [w:] Proceedings of 2008 International Conference on Construction \& Real Estate Management, 1, 564-567.

Litman T., 2007, Land Use Impacts on Transport: How Land Use Factors Affect Travel Behavior, Victoria Transport Institute, Victoria, Canada.

Litwin M., 2003, The role of Intelligent Transportation System (ITS) National Architecture and Standards - the Canadian Experience, [w:] IV Konferencja Naukowo-Techniczna Problemy komunikacyjne miast w warunkach zatłoczenia motoryzacyjnego, Poznań-Będlewo.

Lobo J., Rantisi N., 1999, Investment in infrastructure as a determinant of metropolitan productivity. Growth and Change, 30 (winter), 106-27.

Maat K., Van Wee B., Stead D., 2005, Land use and travel behaviour: expected effects from the perspective of utility theory and activity-based theories, Environment and Planning B: Planning and Design, 32(1), 33-46.

Marczak M., Kozłowski R., 2014, Budowa inteligentnych systemów transportowych jako szansa dla zrównoważonego rozwoju regionów, Ekonomia i Zarzq̨dzanie, 6.

Matysiak A., Kruszewski M., Niezgoda M., Kamiński T., 2013, The analysis of ANPR camera location points in bus lanes monitoring system in the city of Warsaw, Journal of KONES, 20(4), 269-275.

Mikulski J., 2010, October, Using telematics in transport, [w:] International Conference on Transport Systems Telematics, Springer, Berlin, Heidelberg, 175-182.

Milanes V., Villagra J., Godoy J., Simo J., Pérez J., Onieva E., 2012, An intelligent V2I-based traffic management system, IEEE Transactions on Intelligent Transportation Systems, 13(1), 49-58.

Miller J., 2008, June, Vehicle-to-vehicle-to-infrastructure (V2V2I) intelligent transportation system architecture, [w:] Intelligent Vehicles Symposium, 715-720.

Munnell A.H., Cook L.M., 1990, How does public infrastructure affect regional economic performance?, New England Economic Review, Sep, 11-3.
Newman P.W., Kenworthy J.R., 1996, The land use - transport connection: An overview, Land Use Policy, 13(1), 1-22.

Nosal K., 2011, Mobility management concept and examples of its usage in polish conditions, Transport Problems, 6(4), 13-22.

Nosal K., Starowicz W., 2010, Wybrane zagadnienia zarządzania mobilnością, Transport Miejski i Regionalny, 3, 26-31.

Nowak M., Sikora D.A., 2005, Komunalne inwestycje infrastrukturalne w Łodzi w latach 1990-2002 jako czynnik kształtujący przestrzeń miasta, Acta Universitatis Lodziensis. Folia Oeconomica, 186.

Nutley S., Thomas C., 1995, Spatial mobility and social change: the mobile and the immobile, Sociologia $R u$ ralis, 35(1), 24-39.

Qadri M.T., Asif M., 2009, April, Automatic number plate recognition system for vehicle identification using optical character recognition, [w:] Education Technology and Computer, 2009. ICETC'09. International Conference on, 335-338.

Patel C., Shah D., Patel A., 2013, Automatic number plate recognition system (anpr): A survey, International Journal of Computer Applications, 69(9).

Pauer G., 2017, Development Potentials and Strategic Objectives of Intelligent Transport Systems Improving Road Safety, Transport and Telecommunication Journal, 18(1), 15-24.

Preston J., 2001, Integrating transport with socio-economic activity-a research agenda for the new millennium, Journal of Transport Geography, 9(1), 13-24.

Proper A.T., 2001, Intelligent Transportation System Benefits: 2000 Update, U.S. Department of Transportation Washington D.C.

Pucher J., Korattyswaropam N., Mittal N., Ittyerah N., 2005, Urban transport crisis in India, Transport Policy, 12(3), 185-198.

Rastogi R., 2011, Promotion of non-motorized modes as a sustainable transportation option: policy and planning issues, Current Science, 1340-1348.

Robinson A., 2014, August, The use of automatic number plate recognition (ANPR) data in transport model development, [w:] Australian Institute of Traffic Planning and Management (AITPM) National Conference, Adelaide, South Australia, Australia, No. 3.

Robinson A., Van Niekerk A., 2014, Uses of ANPR data in traffic management and transport modelling.

Romanowska A., Jamroz K., 2012, Ruchotwórczość wielkopowierzchniowych obiektów handlowych trzeciej generacji na przykładzie Trójmiasta, Zeszyty Naukowo-Techniczne Stowarzyszenia Inżynierów i Techników Komunikacji w Krakowie. Seria:Materiały Konferencyjne, 2, 98, 179-191.

Rosik P., Komornicki T., 2013, Wpływ budowy autostrad i dróg ekspresowych na rozwój społeczno-gospodarczy i terytorialny Polski, Ministerstwo Rozwoju Regionalnego, Warszawa, 215.

Rudnicki A., Wojnar I., 2009, Ruchotwórczość obiektów 
hotelowych na przykładzie Krakowa, Zeszyty Naukowo-Techniczne Stowarzyszenia Inżynierów i Techników Komunikacji w Krakowie. Seria:Materiały Konferencyjne, 90, 148, 197-214.

Santa J., Gómez-Skarmeta A.F., Sánchez-Artigas M., 2008, Architecture and evaluation of a unified V2V and V2I communication system based on cellular networks, Computer Communications, 31(12), 2850-2861.

Schmeidler K., 2008, Development of transport, mobility and urban form in the Czech Republic, European Spatial Research and Policy, 15 (1).

Shawe-Taylor J., De Bie T., Cristianini N., 2006, September, Data mining, data fusion and information management, [w:] IEE Proceedings-Intelligent Transport Systems, IET Digital Library, 153, 3, 221-229.

Sierpiński G., 2012, Zachowania komunikacyjne osób podróżujących a wybór środka transportu w mieście, Prace Naukowe Politechniki Warszawskiej, 84, 93-106.

Sikora-Fernandez D., 2013, Koncepcja "smart city" w założeniach polityki rozwoju miasta-polska perspektywa.

Singletary L., Henry M., Brooks K., London J., 1995, The impact of highway investment on new manufacturing employment in South Carolina: A small region spatial analysis, The Review of Regional Studies, 25(1), 37.

Slinn M., Matthews P., Guest P., 2006, Traffic engineering design, CRC Press.

Snieska V., Simkunaite I., 2009, Socio-economic impact of infrastructure investments, Engineering Economics, 63(4), 16-25.

Szołtysek J., 2011, Kreowanie mobilności mieszkańców miast, Wolters Kluwer, Warszawa.

Stawasz D., Sikora-Fernandez D., 2015, Dobre praktyki inteligentnego zarządzania w polskich miastach, Studia Miejskie, 19, 35-46.

Szarata A., 2013, Modelowanie liczby pojazdów generowanych przez duże centra handlowe, Prace Naukowe Politechniki Warszawskiej. Transport, (97), 499-508.

Szendro G., 2011, Congestion charging in Budapest-a comparison with existing systems, Periodica Polytechnica. Transportation Engineering, 39(2), 99.
Toral S.L., Torres M.M., Barrero F. J., Arahal M. R., 2010, Current paradigms in intelligent transportation systems, IET Intelligent Transport Systems, 4(3), 201-211.

Tuominen A., Ahlqvist T., 2010, Is the transport system becoming ubiquitous? Socio-technical roadmapping as a tool for integrating the development of transport policies and intelligent transport systems and services in Finland, Technological Forecasting and Social Change, 77(1), 120-134.

Van Wee B., 2002, Land use and transport: research and policy challenges, Journal of Transport Geography, 10(4), 259-271.

Vilhelmson B., 1999, Daily mobility and the use of time for different activities. The case of Sweden, GeoJournal, 48(3), 177-185.

Wang F.Y., 2005, Agent-based control for networked traffic management systems, IEEE Intelligent Systems, 20(5), 92-96.

Wegener M., Fürst F., 1999, Land-Use Transport Interaction: State of the Art. Berichte aus dem Institut für Raumplanung 46. Institut für Raumplanung, Universität Dortmund, Dortmund. http://www.inro.tno.nl/ transland/Deliverable\%202a.pdf.

Wiśniewski S., 2016, Wpływ budowy południkowych obwodnic Łodzi na dostępność mieszkańców miasta do sieci dróg o najwyższych parametrach, Rozwój Regionalny i Polityka Regionalna, 34, 131-143.

Xiong Z., Sheng H., Rong W., Cooper D.E., 2012, Intelligent transportation systems for smart cities: a progress review, Science China Information Sciences, 55(12), 2908-2914.

Yigitcanlar T., Sipe N., Evans R., Pitot M., 2007, A GIS-based land use and public transport accessibility indexing model, Australian Planner, 44(3), 30-37.

Zmuda-Trzebiatowski P., 2016, Dostępność transportowa, a partycypacja w aktywnościach, ubóstwo oraz zagrożenie wykluczeniem społecznym. Autobusy: Technika, Eksploatacja, Systemy Transportowe, 17(12), 754-759. 